\title{
Salt-magma interactions influence intrusion distribution and salt tectonics in the Santos Basin, offshore Brazil
}

\author{
Craig Magee $^{1}$ (D) | Leonardo M. Pichel ${ }^{2}$ ｜ Amber L.Madden-Nadeau ${ }^{3}$ | \\ Christopher A.-L. Jackson ${ }^{2}$ (D) | Webster Mohriak ${ }^{4}$
}

\author{
${ }^{1}$ School of Earth and Environment, \\ University of Leeds, Leeds, UK \\ ${ }^{2}$ Basins Research Group, Department of \\ Earth and Environment, Imperial College \\ London, London, UK \\ ${ }^{3}$ Department of Earth Sciences, University \\ of Oxford, Oxford, UK \\ ${ }^{4}$ Faculty of Geology, Universidade do \\ Estado do Rio De Janeiro, Rio de Janeiro, \\ Brazil
}

\section{Correspondence}

Craig Magee, School of Earth and Environment, University of Leeds, Leeds, UK.

Email: c.magee@leeds.ac.uk

Funding information

Imperial College London

\begin{abstract}
Many sedimentary basins host thick evaporite (salt) deposits. Some of these basins also host extensive igneous intrusion networks. It thus seems inevitable that, in some locations, magma will interact with salt. Yet how interaction between these materials may influence salt tectonics or magma emplacement, particularly at the basin-scale, remains poorly understood. We use 3D seismic reflection data from the Santos Basin, offshore Brazil to image 38 igneous intrusions spatially related to thick Aptian salt. Based on identified seismic-stratigraphic relationships, we suggest sill emplacement likely occurred during the late Albian-to-Santonian. We show intrasalt sills are geometrically similar to but laterally offset from supra-salt sills. We suggest ascending magma was arrested by the salt in some areas, but not others, perhaps due to differences in evaporite lithology. Our mapping also reveals most sills occur within and above the presalt Merluza Graben, an area characterized by Albian-to-Neogene, salt-detached extension. In adjacent areas, where there are few intrusions, salt deformation was driven by post-Santonian diapir rise. We suggest emplacement of hot magma within evaporites above the Merluza Graben enhanced Albian-to-Santonian salt movement, but that crystallization of the intrusion network restricted post-Santonian diapirism. Our work indicates salt-magma interaction can influence salt tectonics, as well as the distribution of magma plumbing systems, and thus could impact basin evolution.
\end{abstract}

\section{K E Y W O R D S}

basin, Brazil, magma, salt, sill, tectonics

\section{1 | INTRODUCTION}

Thick evaporite deposits are common in many sedimentary basins, where they can flow to form a range of salt structures (e.g. diapirs) (e.g. Hudec \& Jackson, 2007; Jackson, 1995; Rowan, 2014; Rowan et al., 2004; Warren, 2006; Warren, 2010). Many salt basins also contain magma plumbing systems, which in places may have intruded earlier salt-formed structures (North Sea, offshore Netherlands, Blažić \& Moreau, 2017; e.g. Danakil Depression, Ethiopia, Schofield et al., 2014). On their own, both salt tectonics and magmatism can impact the evolution of sedimentary basins and continental margins, including the accumulation of natural resources (e.g. Bedard et al., 2012; Holford et al., 2012; 
Jackson \& Hudec, 2017; Peron-Pinvidic et al., 2019; Rohrman, 2007; Schofield et al., 2017; Skogseid et al., 2000; Tari et al., 2003). Yet despite the common occurrence of igneous intrusions in many salt basins, and their importance to basin evolution and natural resource development, we have a poor understanding of how magma may interact physically and chemically with salt, or the potential consequences of such interactions (e.g. Heimdal et al., 2019; Li et al., 2009; López-García et al., 2020; Schofield et al., 2014).

Few structurally oriented studies have explored potential salt-magma interactions (López-García et al., 2020; Schofield et al., 2014; Underhill, 2009). For example, Schofield et al. (2014) showed mechanical variations within the sub-horizontally layered, Werra salt complex, Germany, locally controlled magma emplacement mechanics and intrusion architecture at a metre-scale. In the Werra salt complex, relatively strong halite layers were shown to host vertical dykes emplaced via brittle processes, whereas syn-intrusion heating, dehydration and fluidization of hydrous salt (e.g. carnallite) layers promoted sill emplacement (Schofield et al., 2014). However, it remains unclear whether and how these salt-magma interactions occur at the basin scale (Schofield et al., 2014). For example, can salt bodies provide preferential flow pathways for magma, or do they arrest intrusions and restrict magma distribution (Schofield et al., 2014; Underhill, 2009)? Furthermore, we do not fully know: (a) whether emplacement of hot magma could induce salt flow (López-García et al., 2020; Underhill, 2009); or (b) if the intrusion and crystallization of magma within hydrous salts like carnallite, which can lubricate and facilitate salt movement (e.g. Jackson \& Hudec, 2017; Urai et al., 1986; Van Keken et al., 1993), could locally increase the mechanical strength of the salt and create a rigid framework that restricts salt flow and limits diapirism (e.g. Schofield et al., 2014). There is also a lack of information regarding how the heating and potential melting of salt (e.g. halite melts at ca. $800^{\circ} \mathrm{C}$ ) during intrusion affects the chemistry, rheology and evolution of a magma and/or the formation of associated ore deposits (e.g. Barton \& Johnson, 1996; Heimdal et al., 2019; IaconoMarziano et al., 2017; Li et al., 2009; Mohriak et al., 2009; Pang et al., 2013; Ripley et al., 2003).

There are two key problems that currently limit our ability to answer questions regarding salt-magma interactions. First, field or mine exposures of intrusions within salt allow chemical and small-scale (e.g. metre-scale) structural analysis of salt-magma interactions, but provide little insight into how the whole system may have behaved in 3D at substantially larger scales (e.g. Schofield et al., 2014). Second, seismic reflection images reveal the 3D architecture of entire intrusions, salt structures and halokinetic sequences, but provide little insight into the chemical or small-scale structural processes associated with salt-magma interaction (cf. Blažić \& Moreau, 2017; Underhill, 2009). Integrating field and

\section{Highlights}

- Magma inevitably intrudes salt in some basins, but what are the consequences of such interaction?

- Use seismic reflection images of sills below, within and above salt in the Santos Basin, Brazil.

- We show the salt-trapped ascending magma in places, whereas other areas were bypassed by dykes.

- Intrusion of hot magma enhanced salt flow, but crystallized sills inhibited later salt movement.

- Salt rheology and structure impacts magma plumbing systems, which in turn impacts salt tectonics.

seismic datasets will arguably be critical to addressing the shortcomings associated with each data type.

Here, we use 3D seismic reflection data from the Santos Basin, offshore Brazil, to image the structure of 38 igneous intrusions emplaced below, within and above an Aptian evaporite layer that flowed to form a range of kilometre-scale salt structures. No boreholes in the study area penetrate the salt structures or sills, meaning we cannot directly comment on small-scale structural and chemical salt-magma interactions. However, with our data, we aim to establish the basin-scale structural consequences of salt-magma interactions, allowing us to test whether: (a) the behaviour and rheological properties of salt during emplacement can influence the geometry of individual intrusions and intrusion networks; (b) salt layers can facilitate or inhibit magma ascent and (c) the presence of magma or crystallized intrusions impacts large-scale salt tectonics. By evaluating the consequences of magma intrusion within salt, we anticipate our research will provide a framework for future, integrative studies probing physical and chemical salt-magma interactions at a variety of scales.

\section{2 | GEOLOGICAL SETTING}

The Santos Basin located offshore south-eastern Brazil and formed in the Early Cretaceous (ca. 130-125 Ma; Barremianto-Early Aptian) due to the opening of the South Atlantic Ocean (Figure 1a,b) (e.g. Davison et al., 2012; Mohriak et al., 1995; Quirk et al., 2012). During the post-rift, in the latest Aptian to possibly earliest Albian (ca. 116-111 Ma), a ca. 2- to 3.5-km-thick evaporite-dominated layer was deposited across the basin, covering a sag basin sedimentary succession (Figure 1a,b) (e.g. Davison et al., 2012; Karner \& Gambôa, 2007; Pichel \& Jackson, 2020; Rowan, 2014). 
(a)

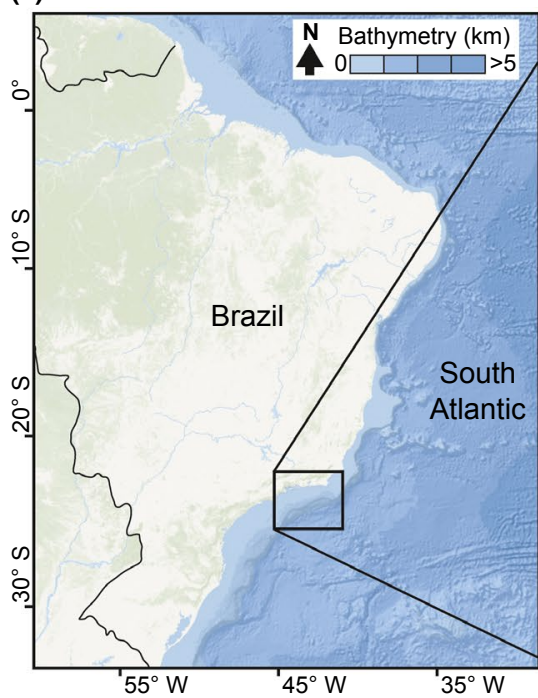

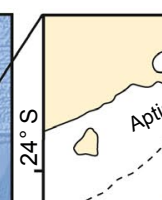

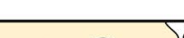

(2)

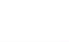

ch

(b)

(c)

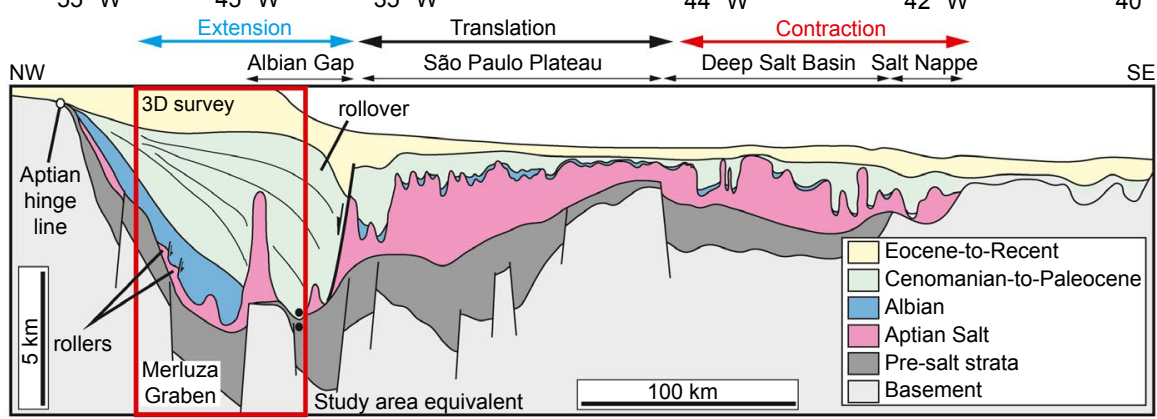

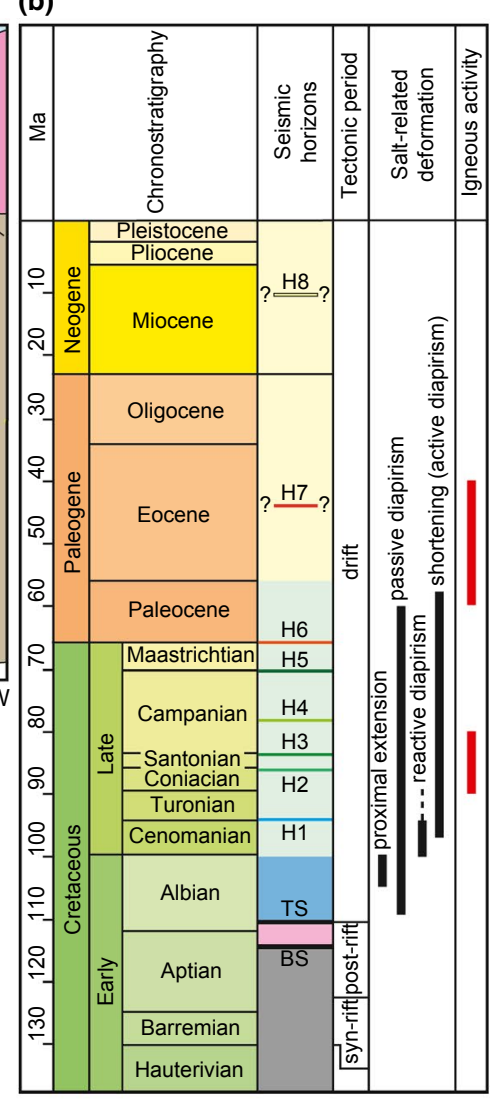

F I G URE 1 (a) Location map of the Santos Basin offshore Brazil, highlighting relevant tectonic and salt-related domains (modified from Davison et al., 2012; Jackson et al., 2015). (b) Tectono-stratigraphic column showing mapped seismic horizons (Duarte \& Viana, 2007; Jackson et al., 2015; Modica \& Brush, 2004; Oreiro et al., 2008). (c) Geoseismic section depicting the passive margin structure of the Santos Basin and the location of the extensional, translational and contractional domains (modified from Davison et al., 2012; Jackson et al., 2015). See Figure 1a for location

Relief across the base salt horizon, a relic of prior rifting (e.g. the Merluza Graben), and at least 12 cycles of basin desiccation and filling controlled initial thickness, compositional and rheological variations within the salt layer (e.g. Davison et al., 2012; Jackson et al., 2015; Pichel et al., 2018; Rodriguez et al., 2018). For example, elsewhere in the Santos Basin, the salt layer can be divided into four units (A1-A4) based on their distinct composition (using borehole data) and seismic expression (Rodriguez et al., 2018). Units A1 and $\mathrm{A} 3$ are characterized by low-frequency, transparent and chaotic seismic facies, and represent halite-rich (>85\%) units, whereas high-frequency, highly reflective seismic facies (A2 and A4) correspond to halite-rich (ca. 65\%-85\% halite) layers that contain relatively high proportions (ca. $15 \%-35 \%$ ) of anhydrite and bittern salts (i.e. $\mathrm{K}$ - and $\mathrm{Mg}$ rich salts) (Rodriguez et al., 2018). Evaporites in our study area were deposited across a prominent presalt rift topography, with base-salt relief of up to ca. $1 \mathrm{~km}$ controlled by ca. NE-trending, high-displacement (ca. 0.5-1 km) normal faults associated with the ca. 150-km-long, up to ca. 4-km-deep, pre- to syn-salt Merluza Graben (Figure 1c) (e.g. Mohriak et al., 2010). Cessation of evaporite deposition in the early Albian marked the establishment of permanent marine conditions in the Santos Basin and formation of a proximal carbonate platform (Figure 1b) (e.g. Karner \& Gambôa, 2007; Meisling et al., 2001; Modica \& Brush, 2004). Igneous intrusions and extrusions were emplaced after salt deposition (116-111 Ma), particularly during discrete phases at ca. 90$80 \mathrm{Ma}$ and ca. 60-40 Ma, across the Santos and Campos basins (see Oreiro et al., 2008 and references therein).

\section{1 | Salt tectonics}

To assess whether the presence of the igneous sills studied locally affected salt tectonic processes, it is important to describe the regional salt tectonic history of the Santos Basin. Salt tectonics across the Santos Basin resulted in the development of kinematically linked domains of up-dip extension, intermediate translation and down-dip contraction and salt extrusion (Figure 1b,c) (e.g. Davison et al., 2012; Demercian et al., 1993; Jackson et al., 2015; Pichel et al., 2018; 
Rodriguez et al., 2018). Regional salt deformation in the Santos Basin started during the Albian, immediately following evaporite deposition (Figure 1b). South-eastwards tilting of the basin as the Brazilian continental margin thermally subsided, produced an array of thin-skinned, salt-detached, normal faults that (Figure 1c): (a) dismembered the Albian succession into extensional rafts and produced salt rollers (cf. Brun \& Mauduit, 2009; Vendeville \& Jackson, 1992) in the up-dip proximal domain, where our study area is located; and (b) instigated down-dip salt inflation and contraction, producing salt anticlines and buckle folds (e.g. Davison et al., 2012; Demercian et al., 1993; Jackson et al., 2015; Quirk et al., 2012). Salt tectonics continued throughout the Late Cretaceous and early Cenozoic as the basin-margin clastic sediments prograded south-eastwards across the salt (Figure 1c) (Davison et al., 2012; Guerra \& Underhill, 2012; Jackson et al., 2015; Pichel et al., 2019). Post-Albian up-dip extension involved continuous development of salt rollers and reactive (i.e. extensional) diapirs, which resulted in the formation of a large ( $>50 \mathrm{~km}$ wide), oceanward-dipping rollover within the Late Cretaceous and early Cenozoic strata (Figure 1c) (e.g. Jackson et al., 2015; Mohriak et al., 1995; Pichel \& Jackson, 2020). Intermediate translation during this period was characterized by the development of ramp-syncline basins, passive diapirs and localized contraction and extension occurring in response to salt movement over a prominent base-salt relief (Figure 1c) (e.g. Dooley et al., 2020; Pichel et al., 2019, 2018). Down-dip contraction was associated with salt thickening, development of salt-cored folds, thrusts and squeezed (active) diapirs, as well as the advancement of a salt nappe beyond the south-eastern edge of the salt basin (Figure 1c) (e.g. Davison et al., 2012; Demercian et al., 1993; Mohriak et al., 2009; Quirk et al., 2012).

\section{3 | DATASET AND METHODS}

We use a ca. 1,000 $\mathrm{km}^{2}$, time-migrated 3D seismic volume, which has a line spacing of 12.5 and $25 \mathrm{~m}$ and a record length of ca. $9 \mathrm{~s}$ two-way travel-time (s TWT). The data were acquired in 2006 using 10, 6-km-long streamers and a shot interval of $25 \mathrm{~m}$ with a sample rate of $2 \mathrm{~ms}$. We present the minimum phase processed data with an SEG (Society of Economic Geologists) normal polarity, whereby a downwards decrease in acoustic impedance corresponds to a positive (red) reflection. We do not have access to any boreholes within the study area so cannot determine seismic velocities for the interval of interest and, therefore, cannot properly constrain the spatial resolution of the seismic data. However, to provide some idea of the data resolution, we use the dominant frequency of the seismic reflection data within the supra-salt strata (ca. $25 \mathrm{~Hz}$ ), salt (ca. $15 \mathrm{~Hz}$ ) and subsalt strata (ca. $20 \mathrm{~Hz}$ ), as well as seismic velocities for these rocks derived from boreholes located elsewhere in the Santos Basin (i.e. well 329D and Tupi 369A; Figure 1a); these data allow us to estimate the limits of separability and visibility (e.g. Brown, 2011). We specifically use seismic velocities of ca. $3.9 \mathrm{~km} / \mathrm{s}$, ca. $4.0 \mathrm{~km} / \mathrm{s}$ and ca. $4.1 \mathrm{~km} / \mathrm{s}$ for the supra-salt strata, salt and sub-salt strata respectively. Our resolution estimates suggest that the limit of separability for the data are $39 \mathrm{~m}$ in the supra-salt strata, $67 \mathrm{~m}$ in the salt and $51 \mathrm{~m}$ in the sub-salt strata; the limits of visibility in these stratigraphic intervals are, respectively, 5, 9 and $7 \mathrm{~m}$. Intrusions thicker than these limits of separability are thus expected to be characterized by discrete top and base reflections, whereas those with thicknesses between the limits of separability and visibility will correspond to tuned reflection packages (i.e. their top and base reflections cannot be deconvolved) (e.g. Brown, 2011; Eide et al., 2018; Magee et al., 2015; Smallwood and Maresh, 2002). Intrusions with thicknesses below the limit of visibility likely will not be identified within the seismic reflection data (Eide et al., 2018). Although the limited resolution information inhibits quantitative analyses of small-scale features (e.g. intrusive steps) and structure dimensions (e.g. sill thickness), it does not impede a comparison between salt structures and igneous intrusions that are typically hundreds of metres to a few kilometres in scale. The lack of well data also means we cannot confidently determine the age or lithology of intrasalt layers (e.g. A1-A4; Rodriguez et al., 2018) or supra-salt strata, although we can still establish relative timings from superposition. To provide some stratigraphic context and chronological framework, we approximately constrain the ages of our mapped horizons through visual comparison to those identified in Pequeno (2009), who used data from 24 confidential, but unnamed, boreholes (Figure 1b).

\section{1 | Horizon mapping}

We mapped the top salt (TS), which corresponds to the near Top Aptian and approximate base salt (BS) horizons (Figures $1 \mathrm{~b}$ and 2). Time-structure maps of BS and TS provide information on the presalt basin structure and post-depositional deformation of the salt respectively. We also mapped eight supra-salt salt horizons to constrain the present geometry of the overburden (Figures $1 \mathrm{~b}$ and 2). Based on comparison to horizons dated by Pequeno (2009), we mapped (Figures $1 \mathrm{~b}$ and 2): H1 = near CenomanianTuronian boundary; $\mathrm{H} 2=$ near Coniacian-Santonian boundary; $\mathrm{H} 3=$ near Top Santonian; H4 = intraCampanian; H5 = near Top Campanian; H6 = near Top Cretaceous; $\mathrm{H} 7=$ intra-Palaeogene and $\mathrm{H} 8=$ intraNeogene. Time-thickness (isochore) maps record changes in salt-controlled accommodation between these supra-salt horizons, which allowed us to unravel the salt deformation history. To quantify how stratal thickness varies across 
F I G URE 2 (a and b) Uninterpreted and interpreted, time-migrated seismic sections across the study area showing a sample of the different salt structures, halokinetic sequences and intrusions present. See Figure 3 for line locations some salt-detached faults, we calculated expansion indices; i.e. the ratio of the hanging wall thickness of a sedimentary sequence to its footwall thickness (e.g. Thorsen, 1963). Expansion indices $>1$ for a stratigraphic unit indicate the fault was surface breaking during its deposition, with fault slip accommodating additional sediment and an overall
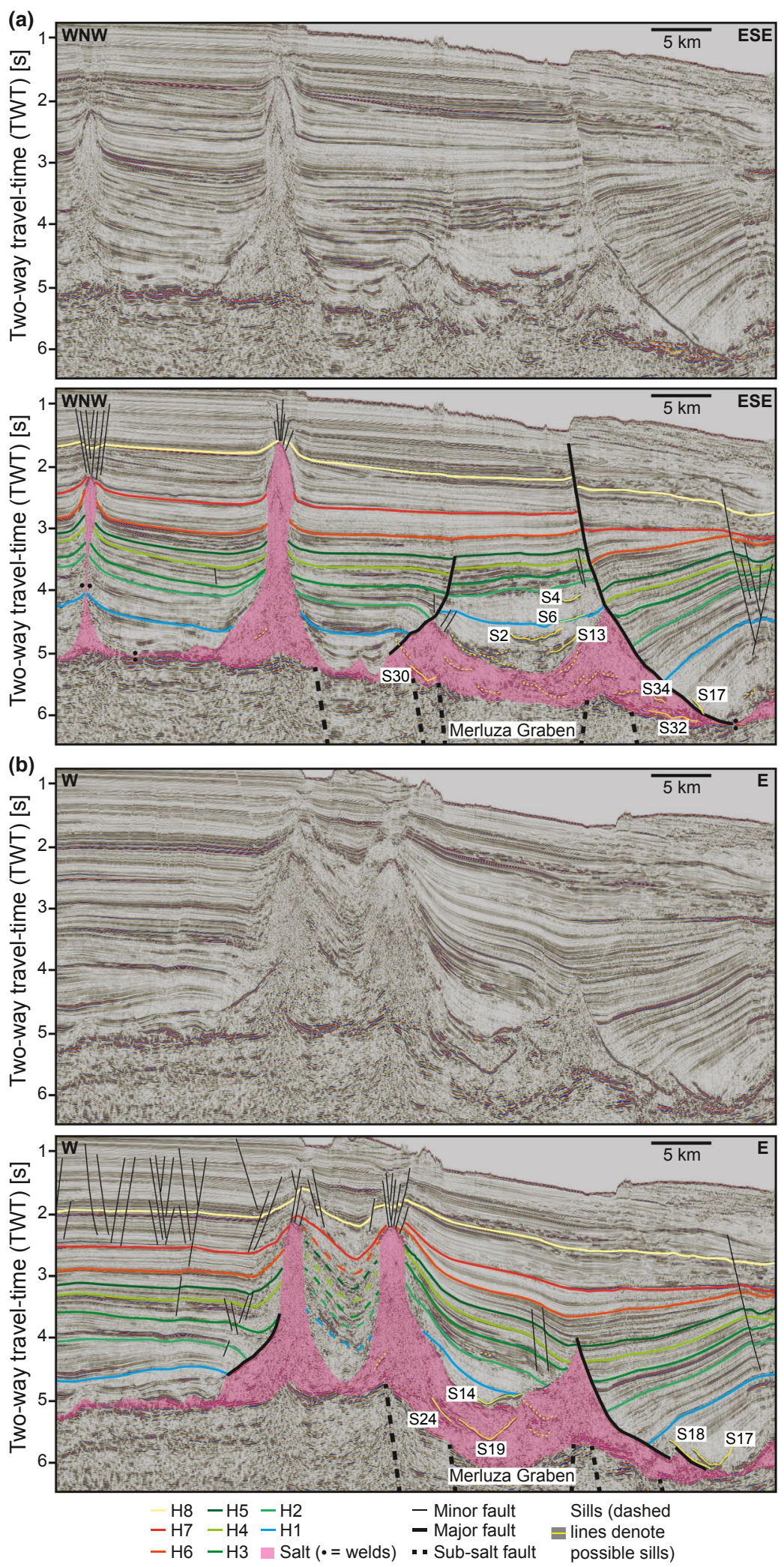

thicker succession in its hanging wall, compared to its footwall (e.g. Thorsen, 1963).

We mapped 38 igneous intrusions based on whether their corresponding reflections were high-amplitude, positivepolarity, laterally discontinuous (on a kilometre scale) and/ or transgressed background stratigraphic or salt-related 
(a)

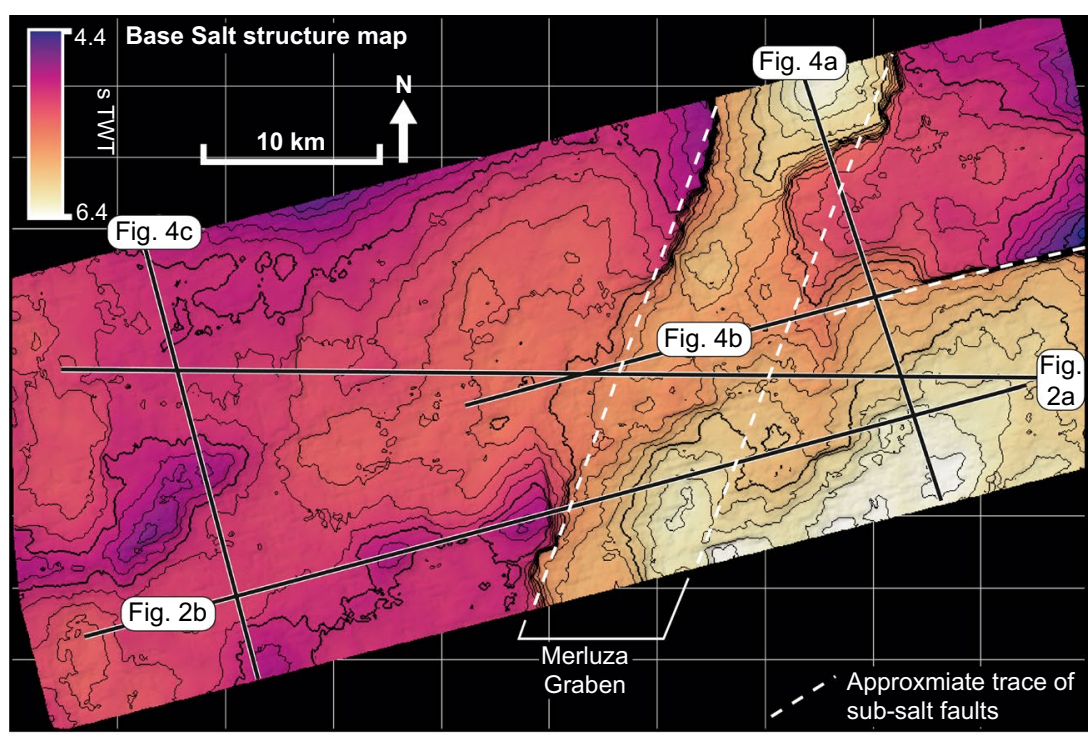

(b)

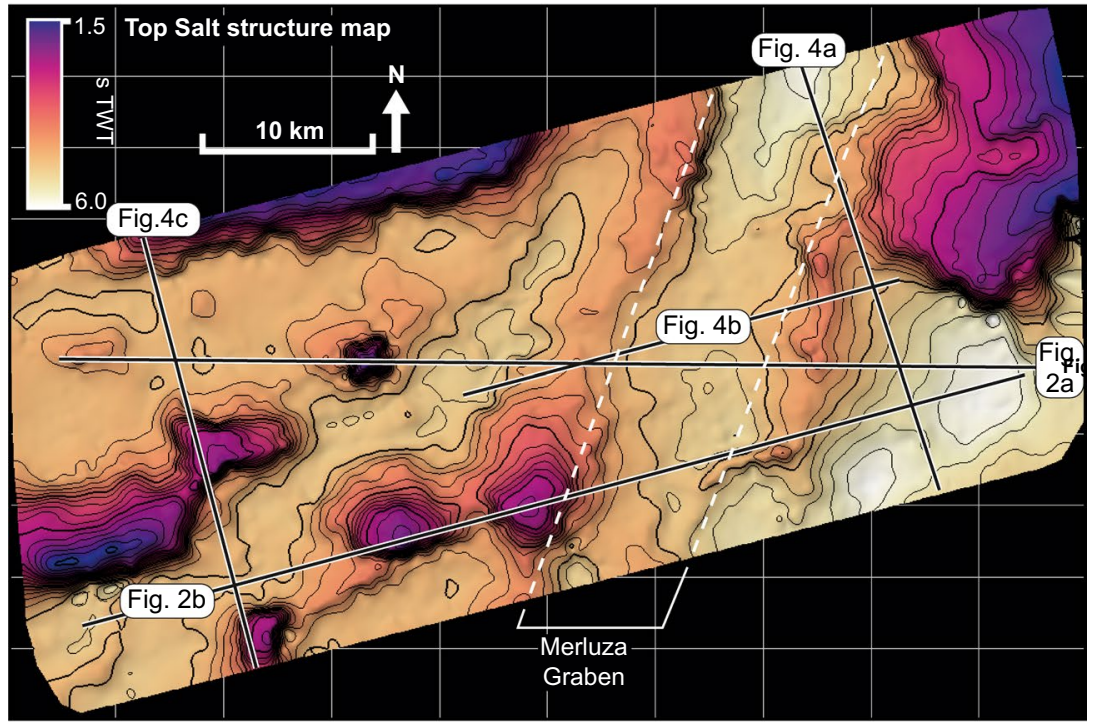

(c)

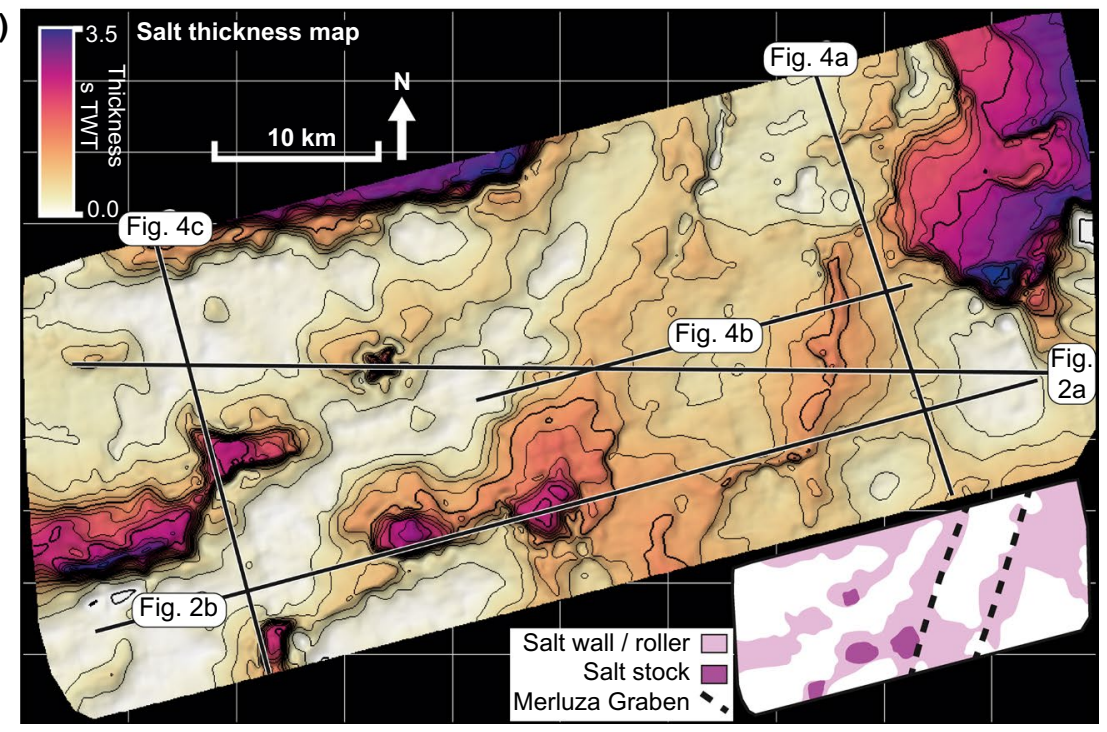

FIG URE 3 Time-structure maps of the (a) Base Salt and (b) Top Salt horizons, and (c) an isochore map showing the vertical thickness in time between the Base and Top Salt horizons. Salt structure distribution is interpreted in (c) reflections (e.g. Planke et al., 2005). Each intrusion is expressed as a tuned reflection package, whereby seismic energy returned from the top and base contacts convolves as it travels back to the surface and cannot be distinguished (e.g. Figure 2) (e.g. Brown, 2011). For the 18 mapped intra-salt sills, it is plausible that their high-amplitude, positive polarity 
and discontinuity could be attributed to the presence of relatively dense and/or high-velocity salt lithologies (e.g. anhydrite, carbonate and carnallite) within encasing halite (e.g. Jackson et al., 2015; Rodriguez et al., 2018). However, we observe that, in places, sub-salt and intra-salt reflections cross-cut BS and TS respectively; the strata-discordant nature of these reflections, which do not offset horizons, supports our interpretation that they correspond to igneous intrusions (e.g. Planke et al., 2005). We recognize other high-amplitude, positive-polarity, laterally discontinuous reflections within the salt, but could not confidently map these as they display complex, incoherent geometries in 3D (e.g. Figure 2); i.e. we could not establish whether these reflections document fragments of igneous material, which perhaps derived from more continuous intrusions that were deformed during later salt movement, or other intra-salt material (e.g. clastic or carbonate stringers). Furthermore, we acknowledge that thin sills, with thicknesses below the limit of visibility of the data, may not be recognized within the data (e.g. Eide et al., 2018; Schofield et al., 2017). No dykes were identified in the seismic reflection data, although their likely sub-vertical orientation commonly inhibits their imaging so we cannot preclude their presence (see Magee \& Jackson, 2020 and references therein).

For each interpreted intrusion, we measure their long axis, short axis, area and transgressive height where applicable; these values should be considered minimum bounds as many intrusions thin towards their lateral tips and thus their measurement is limited by the resolution of the data (Eide et al., 2018; Magee et al., 2015). We acknowledge human error may introduce further uncertainties into our measurements and thus conservatively consider they may have errors of up to 5\%. Finally, without borehole information, we cannot determine the absolute age of the intrusions. In some instances, we observe and describe vent-like features and intrusioninduced forced folds, which mark possible syn-intrusion palaeosurfaces and thus allow us to determine the relative age of the associated intrusions (e.g. Trude et al., 2003). Most intrusions are not associated with vents or forced folds, so we use the estimated age of the strata they were intruded into as a proxy for their maximum possible age of emplacement.

\section{4 | RESULTS}

\subsection{Salt seismic expression}

The interpreted Base Salt (BS) corresponds to a complex and discontinuous stack of high-amplitude, commonly positive polarity reflection packages mapped between ca. 4.5 and 6.5 s TWT (e.g. Figures 2 and 3a). The Top Salt (TS) corresponds either to a high0amplitude, positive-polarity reflection or, where salt structures have vertical or overhanging margins, the transition between intra-salt chaotic reflections and sub-parallel reflections of the supra-salt sequence (e.g. Figures 2 and $3 b$ ). The salt itself is generally internally defined by chaotic, discontinuous, low-to-moderate reflections, particularly where it is thickest (e.g. Figure 2). In places, the salt locally contains high-amplitude, more continuous reflections (e.g. Figure 2).

\subsection{1 | Sub-salt structure}

A key structural feature observed on the BS horizon is a linear, NNE-trending trough that marks the location of the underlying Merluza Graben (Figures 2 and 3a). The edges of the trough coincide with the upper tips of graben-bounding, inward-dipping, moderate throw (ca. 0.2-0.5 s TWT) normal faults (Figures 2 and 3a). East of the Merluza Graben is a relatively flat-topped structural high (ca. $4.5 \mathrm{~s}$ TWT tall), which is separated from a ca. $6.5 \mathrm{~s}$ TWT deep depocentre to the south by a large throw (ca. $1 \mathrm{~s}$ TWT), ENE-WSW striking and S-dipping normal fault (Figures $3 \mathrm{a}$ and $4 \mathrm{a}$ ). To the west of the Merluza Graben, the BS horizon is defined by a broad, relatively flat-topped terrace (Figure $3 \mathrm{a}$ ). The few dome-like structural highs on this terrace underlie salt structures and likely correspond to velocity pull-up artefacts (Figures 2 and 3a).

\subsection{2 | Salt structure}

Our study area is characterized by variably oriented salt walls and stocks with variable orientations (Figure $3 b, c)$. West of the Merluza Graben we observe ca. 20-30 km long, ca. 3-5 km wide, ENE-trending walls, which have with reliefs of up to ca. $3 \mathrm{~s}$ TWT (Figures 2 and $3 \mathrm{~b}, \mathrm{c}$ ). Stocks that are up to ca. 3-3.2 s TWT tall and ca. 1-2 km wide rise from low-relief (ca. 0.5-1 s TWT) walls in this western area (Figures 2, 3b,c and 4). These stocks have overhanging flanks and, locally, may be welded (e.g. Figure 2a). East of the Merluza Graben, a ca. $10 \mathrm{~km}$ wide, $>15 \mathrm{~km}$ long and ca. 3.5s TWT tall wall is present (Figure $3 b, c$ ). Thin or nearly welded salt occurs below minibasins developed adjacent the moderate- to highrelief walls and stocks (Figure 3c).

In contrast to the walls in the western and eastern portions of the study area, the two walls developed above the bounding faults of the Merluza Graben trend NNE-SSW, sub-parallel to the graben axis, and are ca. 15-30 km long, ca. $3 \mathrm{~km}$ wide and 1-1.2 s TWT tall (Figure 3b,c). These two walls occur in the immediate footwall of and are bound on one side by salt-detached listric faults that dip away from the graben axis (e.g. Figures 2, $3 b, c$ and $4 b$ ). Given these diapirs are bound by and perhaps genetically related to salt-detached faults, we refer to them as salt rollers (sensu Bally, 1981; Brun \& Mauduit, 2009). The western 


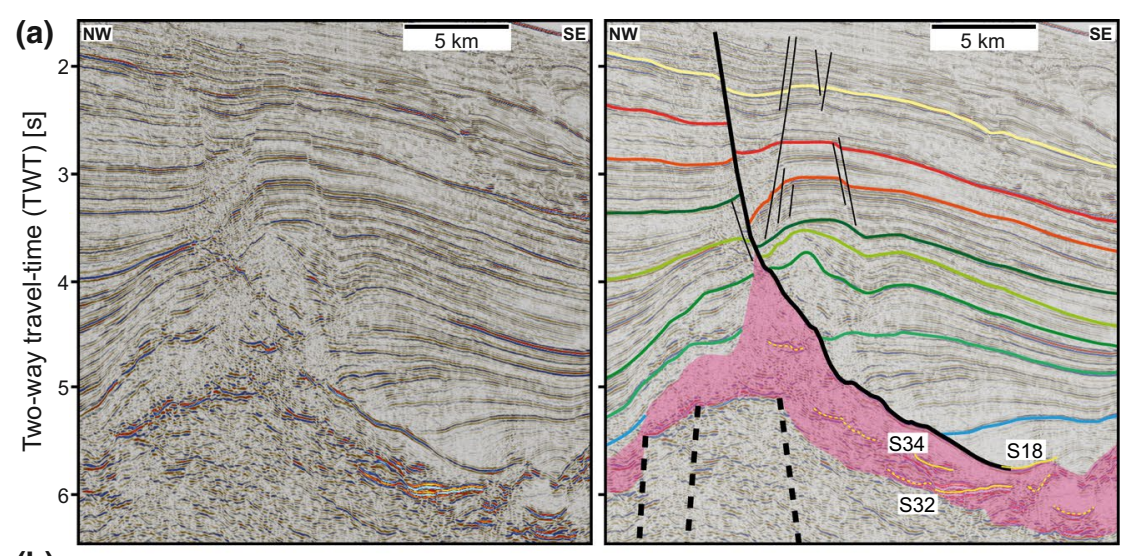

F I G URE 4 (a-c) Uninterpreted and interpreted, time-migrated seismic sections across the study area showing a sample of the different salt structures, halokinetic sequences and intrusions present. An inferred vent associated with sill emplacement is shown in (b). See Figure 2 for key and Figure 3 for line locations
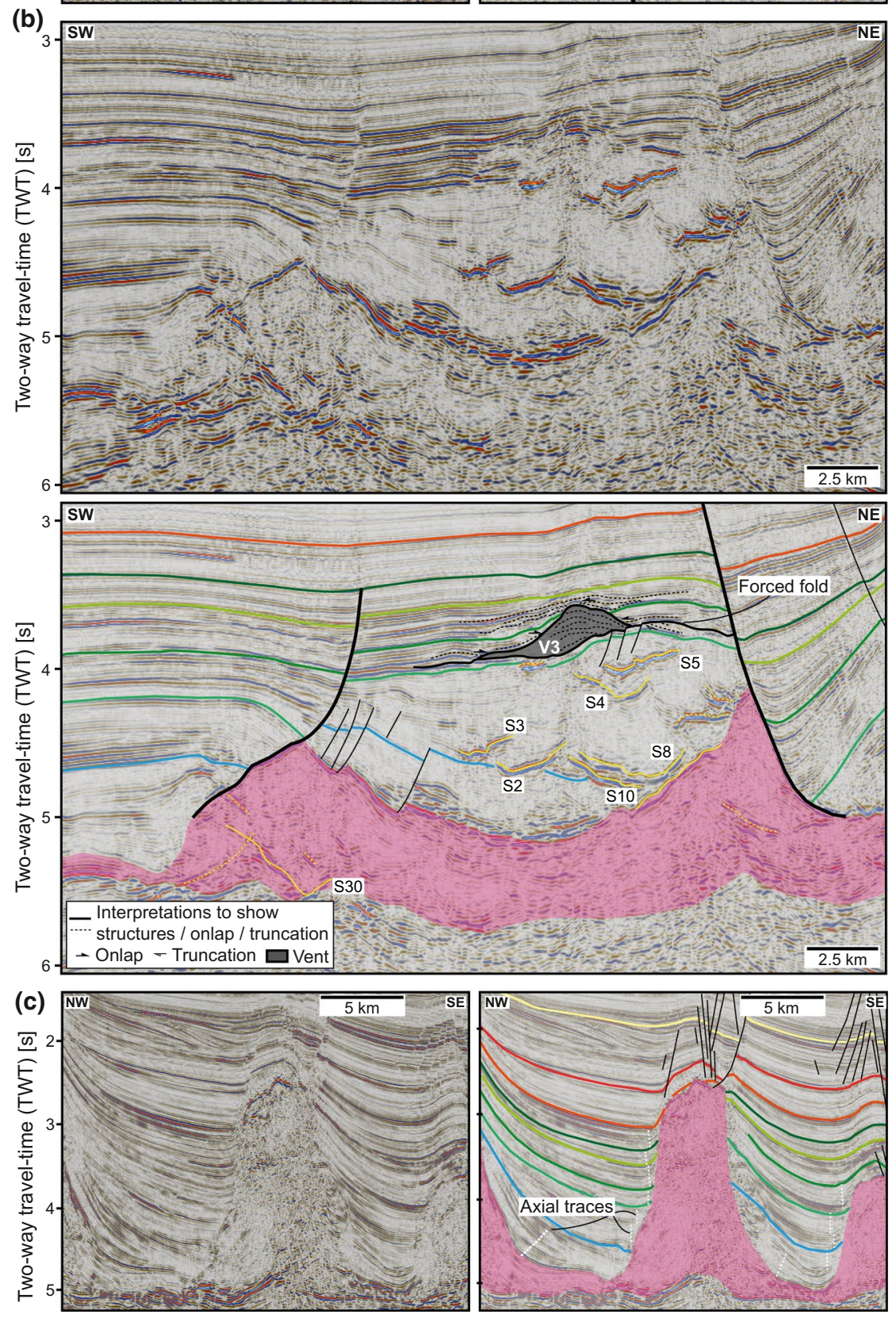

roller is defined by a landward (west)-dipping fault that is up to ca. $2 \mathrm{~s}$ TWT tall and offsets the Cretaceous succession up to H5 (near Top Campanian) by ca. $0.5 \mathrm{~s}$ TWT (e.g. Figures 3b,c and $4 \mathrm{~b})$. The eastern roller is bound by a basin-ward (east)-dipping, listric normal fault that is up to ca. $4.5 \mathrm{~s}$ TWT tall and offsets the Cretaceous and most of the Cenozoic succession, extending above H8 (intra-Neogene) by ca. 0.5-1 s TWT (e.g. Figures $3 b, c$ and $4 b$ ). A stock is developed near the Merluza 
Graben where the western roller intersects the eastern end of an ENE-WSW trending wall (Figure 3b,c). Within the limits of, and immediately above, the Merluza Graben, salt thickness broadly decreases northwards from ca. 1.45 to ca. $0.05 \mathrm{~s}$ TWT (Figure 3c).

\subsection{3 | Supra-salt structure}

The NNE-trending rollers developed above the edges of the Merluza Graben are associated with salt-detached faults containing very thick, wedge-shaped packages of growth strata in their hanging walls (Figures $4 \mathrm{~b}$ and 5). For the western and eastern rollers, growth strata within their extensional rollovers are of Albian-to-Campanian (including H1-H5) and Albian-to-Neogene (including H1-H8) age respectively (Figures $4 \mathrm{~b}$ and 5). The greatest expansion indices of 2.7 and 3.4 for the western and eastern faults, respectively, are recognized at H3 (Top Santonian) (Figure 6); below and above $\mathrm{H} 3$, expansions indices for both faults are typically $<1.5$, except for $\mathrm{H} 4$ at the eastern fault where the expansion index is $>2.5$ (Figure 6). The shared footwall of the roller-bounding,
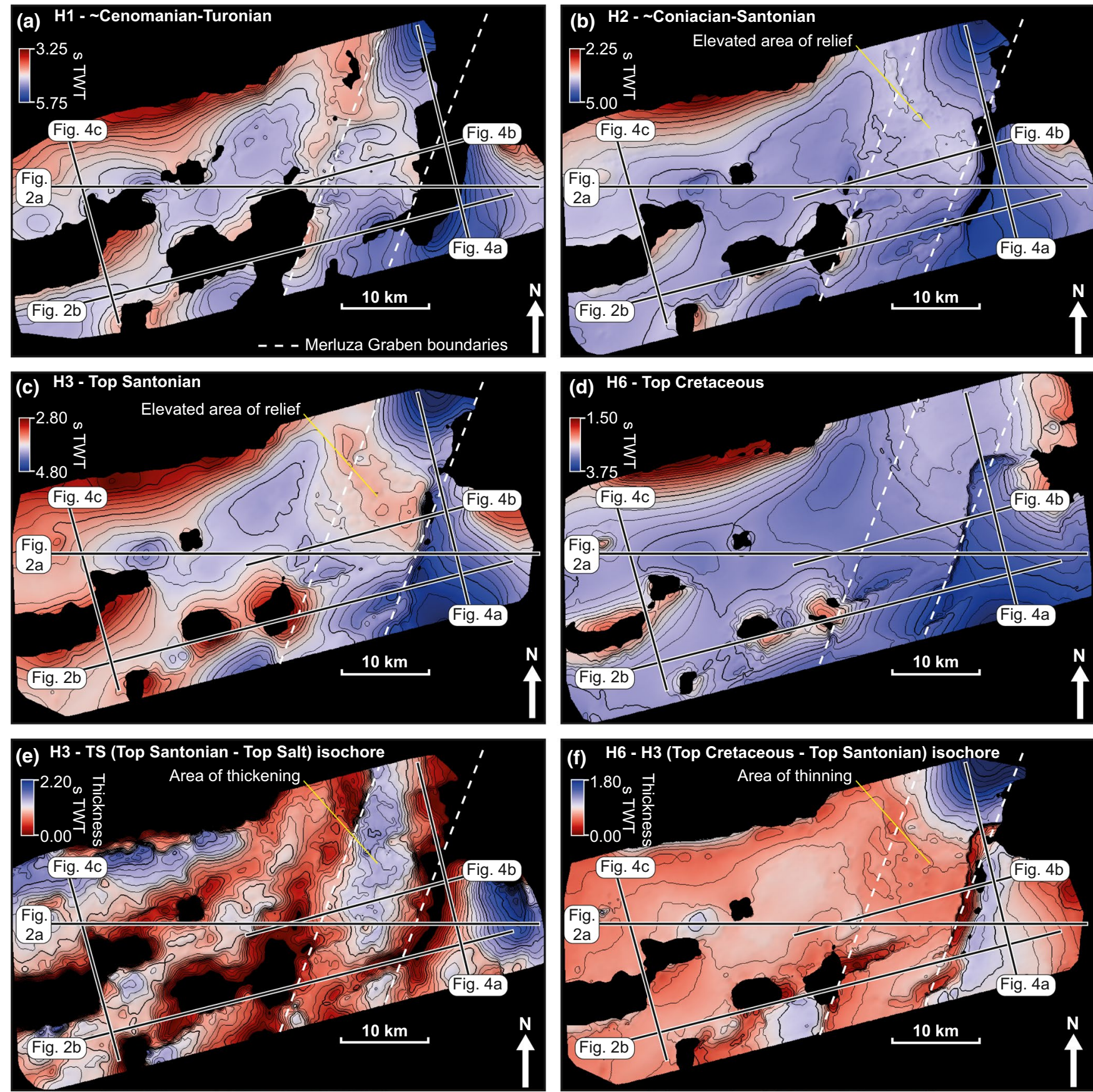

F I G U RE 5 (a-d) Time-structure maps of H1, H2, H3 and H6. (e and f) Isochore thickness maps for the Top Santonian-to-Top Salt horizons and the Top Cretaceous-to-Top Santonian horizons respectively 
salt-detached faults is defined by a Albian-to-Santonian (TSH3) minibasin, characterized by stratal thickening above a broad, sag-like depression in TS (Figures 4b and 5).

Away from the Merluza Graben and its overlying rollers, salt diapirs are flanked by 3-4 s TWT thick, Upper Cretaceous-to-Lower Cenozoic minibasins (Figures 2, 4c and 5). Composite halokinetic sequences, defined by thinning and upturn of strata at the diapirs flanks (sensu Giles \& Rowan, 2012; Pichel \& Jackson, 2020), are present at the edges of these minibasins between H2 (near ConiacianSantonian boundary) and H7 (intra-Palaeogene) (e.g. Figures 2 and 4c). An earlier, Albian-to-Turonian (TS-H1) phase of longer-wavelength, minibasin-scale $(>1 \mathrm{~km})$ folding and stratal thinning is observed adjacent to some of these stocks (Figures 2b and 4c).

\subsection{Igneous intrusions}

\subsection{1 | Seismic expression and distribution of intrusions}

We mapped 38 intrusions in the 3D seismic reflection data, with 18 located above the salt (S1-S18), 18 within the salt (S19-S36) and 2 below the salt (S37-S38) (Figure 7). Each intrusion corresponds to high-amplitude, positive-polarity, tuned reflection packages (e.g. Figures 2, 3, 7 and 8). The intrusions are laterally discontinuous and typically appear circular to elliptical in plan-view (e.g. Figures 2, 3, 7 and 8). We classify intrusions as either sub-horizontal sills, saucershaped sills or inclined sheets (e.g. Figures 2, 3, 7 and 8).

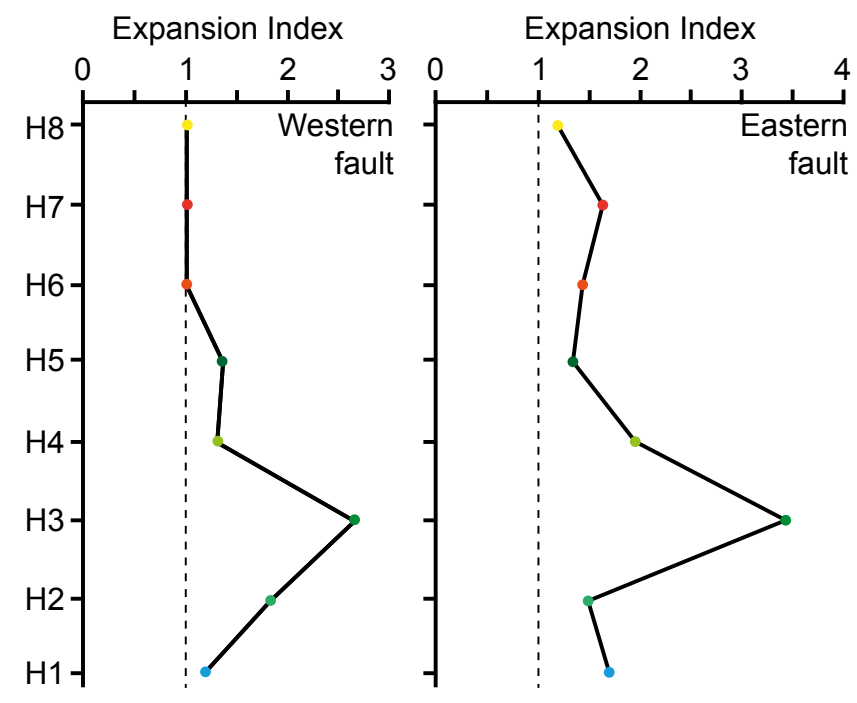

F IG URE 6 Expansion index plots for the western and eastern listric faults above the Merluza Graben measured from the seismic line shown in Figure 4b
Saucer-shaped sills display inwardly inclined limbs that fully or partially encompass (i.e. they have arcuate strikes) and extend upwards from a flat or inclined inner sills (e.g. S1 and S10; Figure 8a,b). Inclined sheets may also extend upwards from a small sill, but these are planar rather than arcuate (e.g. S13; Figure 8c).

Of the 18 intrusions that occur within the Cretaceous strata above TS, the majority (14; S1-S14) occur along a ca. 10-km-wide, N-trending zone situated above the Merluza Graben (Figure 8a-c). Intrusions above the Merluza Graben are only observed where salt thickness is ca. $<1 \mathrm{~s}$ TWT (Figures 3c and 7d). Two intrusions (S15-S16) above TS are located ca. $5 \mathrm{~km}$ to the west of the Merluza Graben, whereas $\mathrm{S} 17$ and S18 are located ca. $5 \mathrm{~km}$ to the east, where the salt is $<0.5$ s TWT thick (Figure 7a,d). Intrusions above TS display either saucer-shaped (S1-S10, S17) or inclined sheet (S11S16, S18) morphologies (Figures 2, 4b, 7b,c and 8; Table 1); of the seven inclined sheets, seismic-stratigraphic relationships reveal two (S12-S13; e.g. Figure 8c) are concordant with dipping strata and four (S14-S16, S18) are transgressive (e.g. Figure 2). Parts of S17 and S18 coincide with the TS horizon where it is faulted against syn-kinematic stratal packages (e.g. Figure 2b). Two intrusions (S17-S18) are confined to strata between TS and H1 (near Cenomanian-Turonian boundary), whereas 15 intrusions (S2-S16) predominantly located within this stratal package extend above H1 (e.g. Figures 2, 4b and 8c). One intrusion, a saucer-shaped sill (S1), is located above H2 (near Coniacian-Santonian boundary) (Figure 8a).

Of the 18 intrusions that primarily occur within the salt, seven (S19-S25) are hosted by a NW-trending wall near the southern limits of the Merluza Graben (Figure 7a,d,e); the upper tip of S21 extends above TS into the overlying Cretaceous strata. Most other intra-salt intrusions occur beneath the flanks of stocks west of the Merluza Graben (Figure 7d). S33 is located at the edge of a large salt wall to the east of the Merluza Graben, whereas S32 and S34 are situated within a $<0.5 \mathrm{~s}$ TWT thick portion of a salt roller (Figures $4 \mathrm{a}$ and $7 \mathrm{~d}$ ). We describe four intra-salt sills as saucer-shaped (S19, S21, S32 and S34), two as subhorizontal (S26-S27) and 12 as inclined sheets (S20, S22S25, S28-S29, S31, S33 and S35-S36) (e.g. Figures 2, 4a,b; Table 1). We map two transgressive sills (S37-S38) below the salt (Figure 7a,e); these both extend upwards into and terminate within the salt.

The tuned reflection packages representing the suprasalt intrusions are commonly segmented by local variations in amplitude and dip (e.g. Figure 8a,b); intra-salt intrusions do not appear to be similarly segmented (e.g. Figures 2, 4b and 8). Aside from marking the transition from the inner sill to inclined limbs within saucer-shaped intrusions, changes in dip typically correspond to abrupt, yet small (typically $<0.05 \mathrm{~s}$ TWT high), vertical offsets in reflections where 
(a)

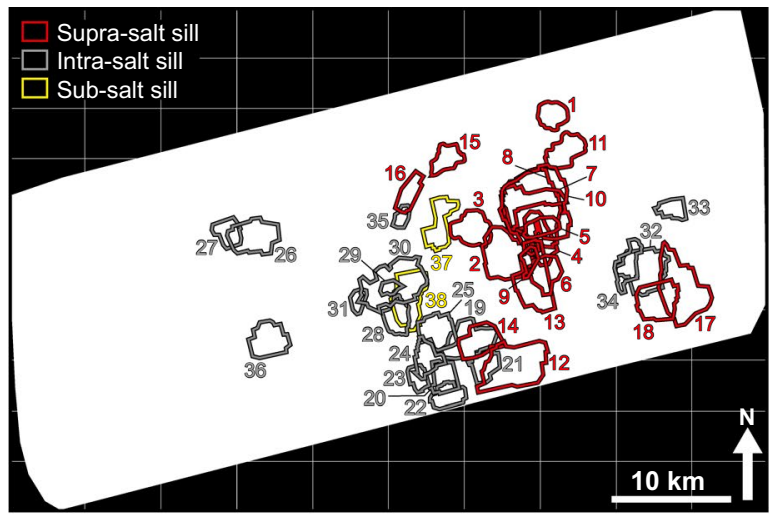

(c)

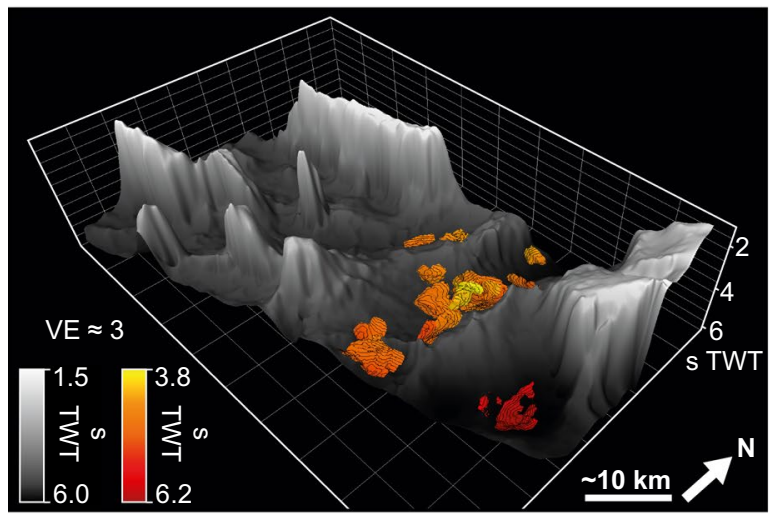

(e)

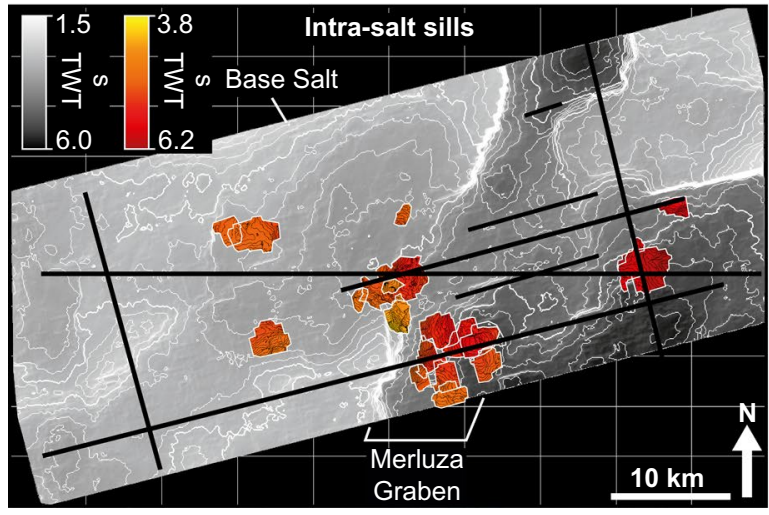

(b)

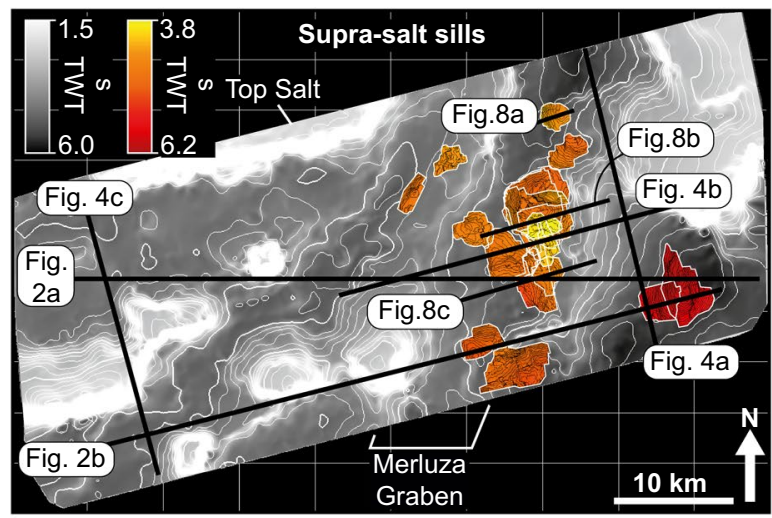

(d)

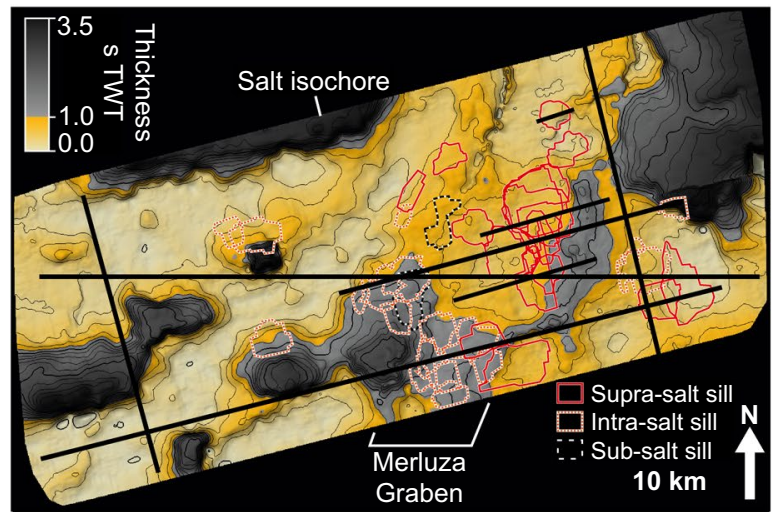

(f)

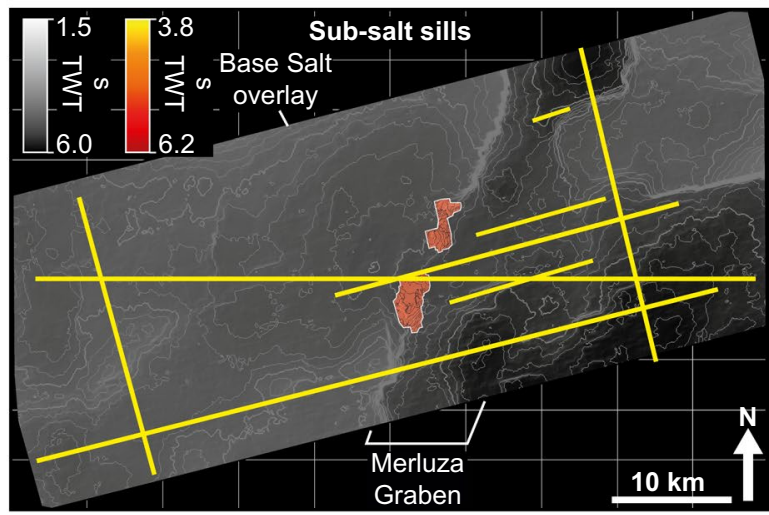

F I G U RE 7 (a) Map of sill outlines highlighting those observed below, within and above the salt. (b) Supra-salt sill time-structure maps shown above the Top Salt horizon time-structure map. (c) Oblique 3D view of (b). Vertical exaggeration = VE. (d) Sill outline maps overlaid onto salt isochore map. (e) Intra-salt sill time-structure maps shown above the Base Salt horizon time-structure map. (f) Sub-salt sills beneath the Base Salt horizon. Figure locations (black/yellow lines) highlighted but only labelled in (b) for clarity

host rock strata is transgressed (e.g. Figure 8a,b). Although the distribution of these linear steps is commonly complex, they tend to occur either parallel to the strike of transgressive sheets (e.g. Figure 8a) or radiate outwards from the deepest portion of a sill (e.g. Figure 8b). Amplitude variations are also complex but numerous intrusions display arrays of linear, high-amplitude zones adjacent, and parallel, to the small vertical offsets (e.g. Figure 8a,b); some linear high-amplitude zones occur independent of changes in reflection dip, particularly around the outer edges of saucershaped sills.

\subsubsection{Quantitative intrusion analysis}

The 38 mapped intrusions have long axes ranging from 1.64 to $6.42 \mathrm{~km}$, and areas of $1.28-27.85 \mathrm{~km}^{2}$. Intrusion aspect ratios vary from 1.06 to 2.78 , with a mean of 1.64 and standard deviation of 0.44 , indicating most are sub-circular (Table 1). Although we define three distinct intrusion populations based on their stratigraphic relationship to the salt (i.e. sub-salt, intra-salt and supra-salt), there is little difference in their geometrical properties (Figure 9). For example, cross-plotting long axes length, intrusion height, area and aspect ratio reveal 

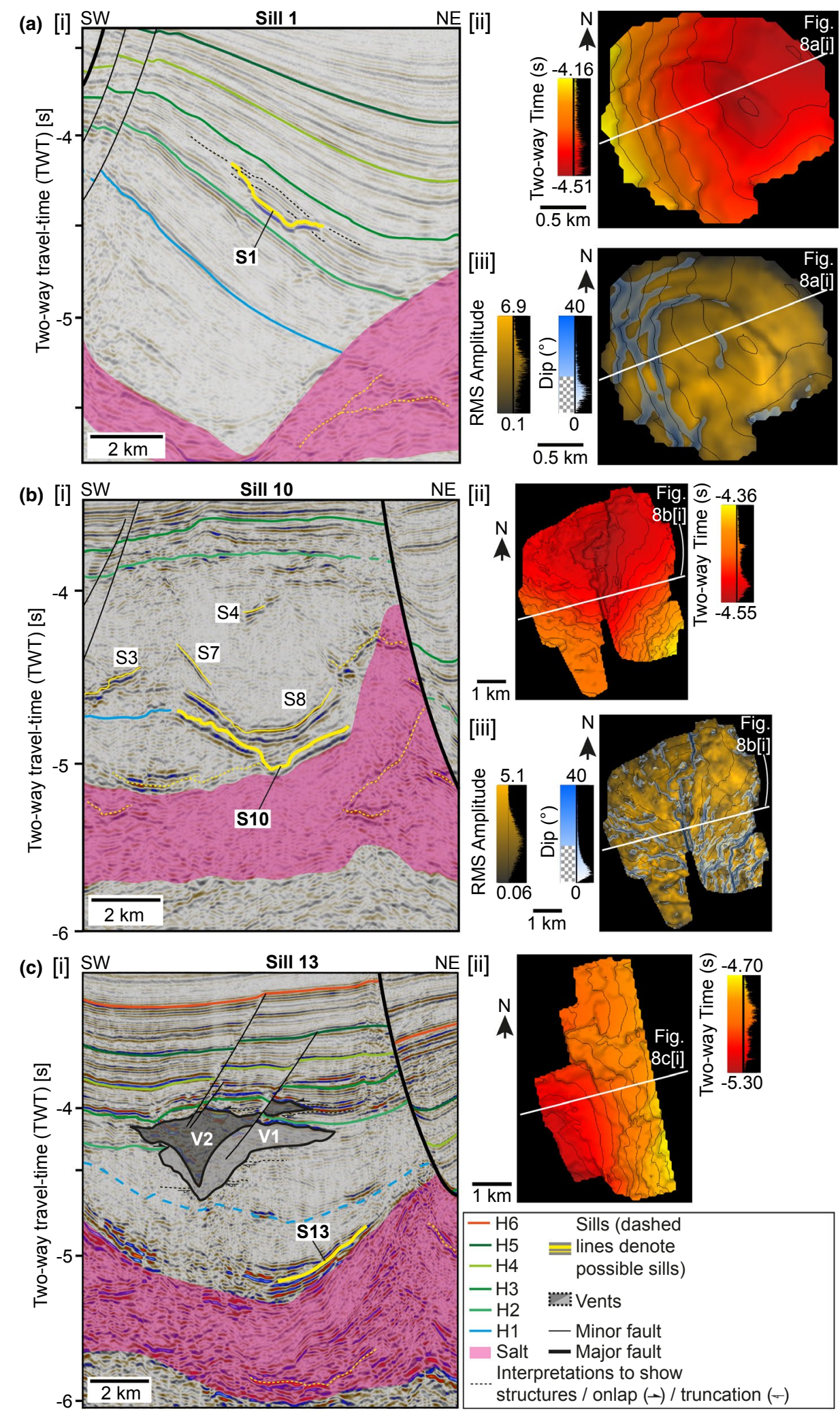

F I G U RE 8 (a-c) Interpreted seismic sections showing examples of sills and inferred vents in the study area; see Figure S1 for uninterpreted sections. Time-structure maps, as well as combined root-mean squared (RMS) amplitude and dip maps highlight the plan-view geometry of key sills

all intrusion populations overlap and display similar trends (Figure 9). A notable exception is that the four largest intrusions, in terms of their long axis and area, occur above TS (i.e. S8, S10, S12 and S17; Figure 9 and Table 1). Supra-salt intrusion transgressive height is moderately to strongly, positively correlated with both area and long axis $\left(R^{2}=.60\right.$ and 


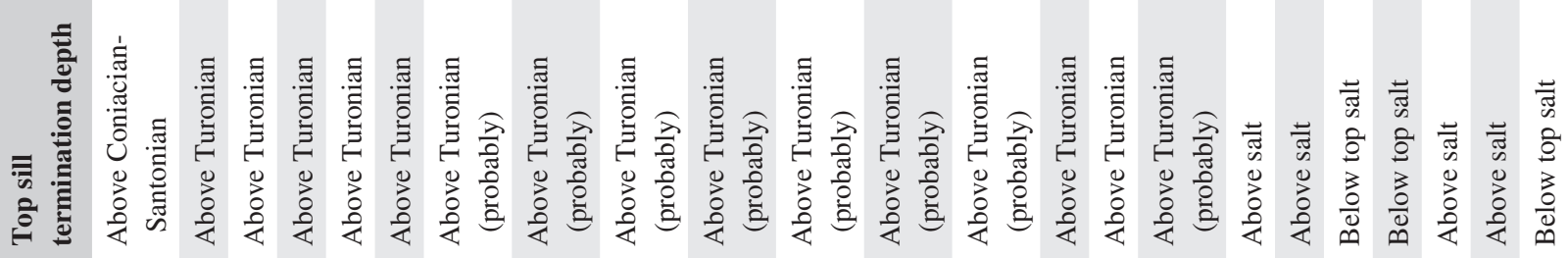

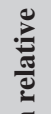

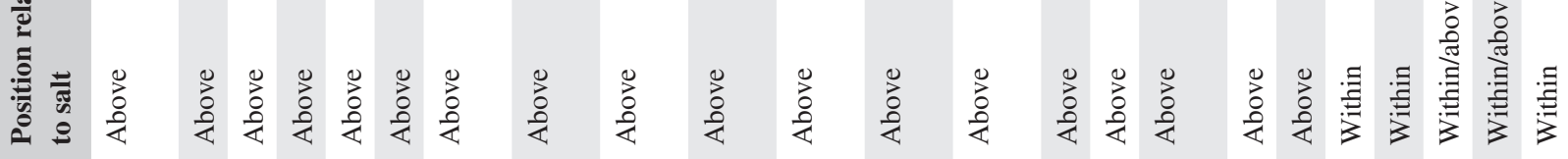

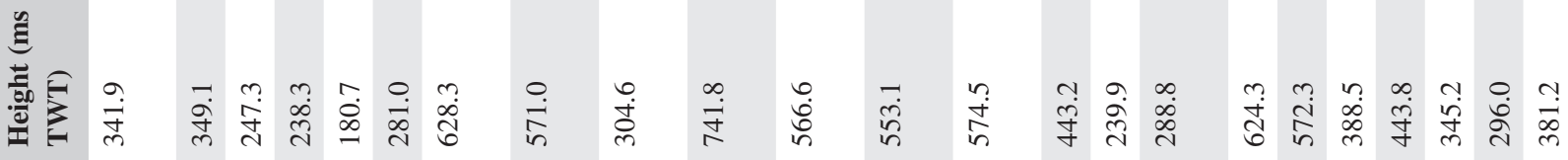

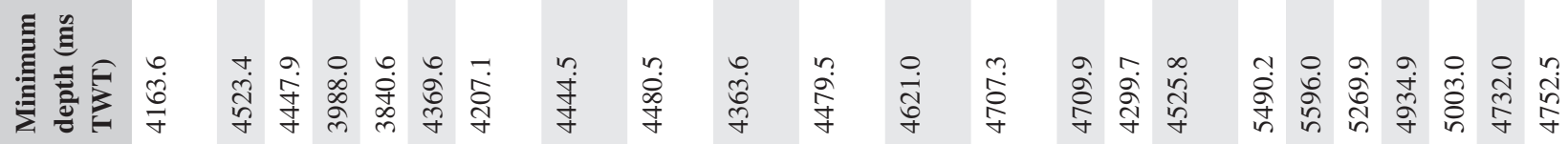

产

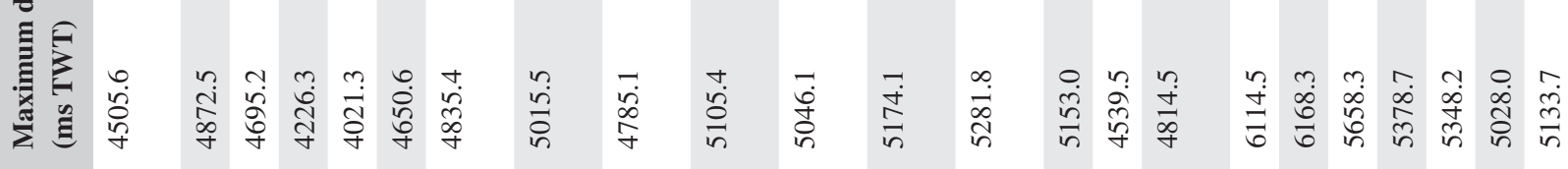

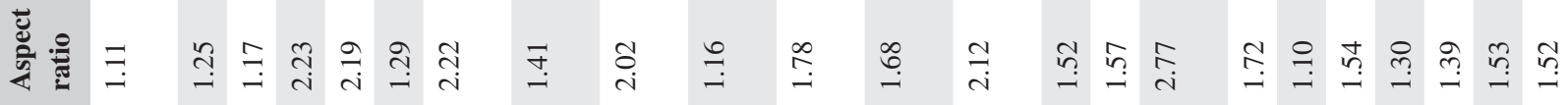

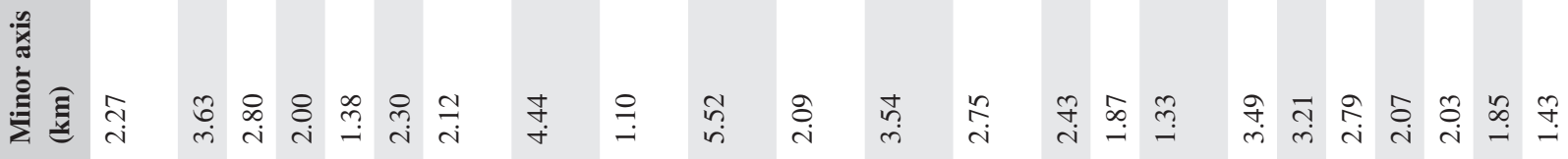

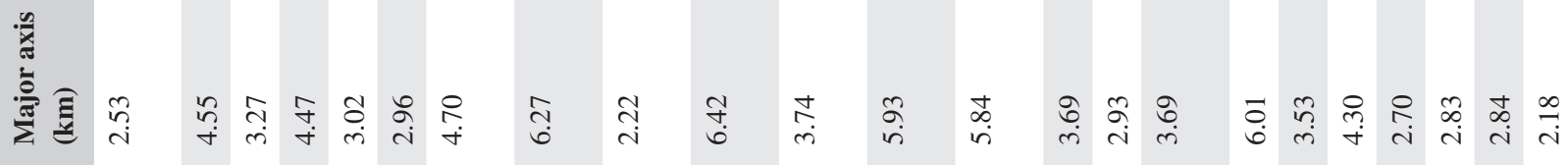

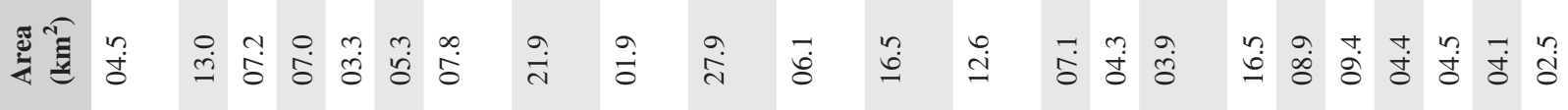

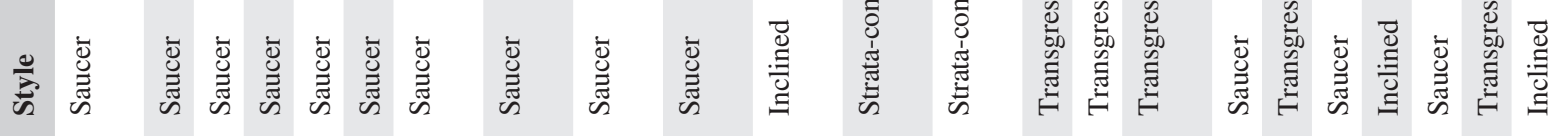

$\stackrel{-1}{-5}$

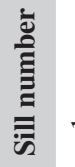

$4 m+n \ln$

$\infty \quad \therefore=\cong$

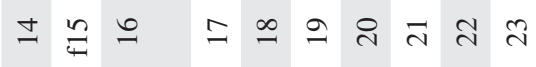




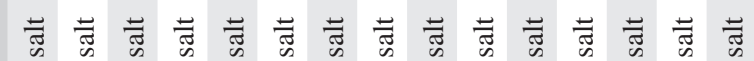

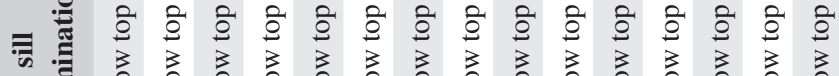

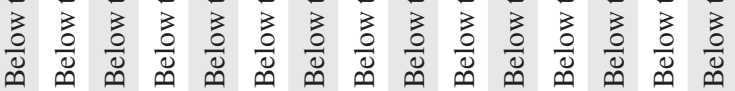

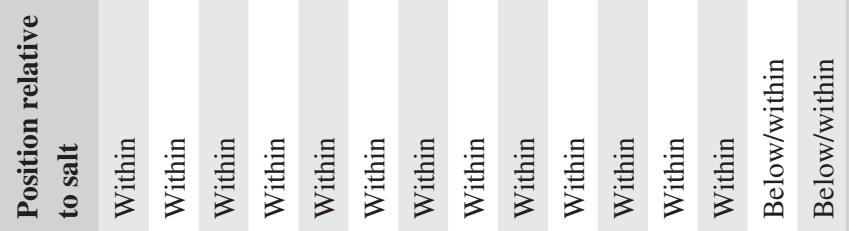

है

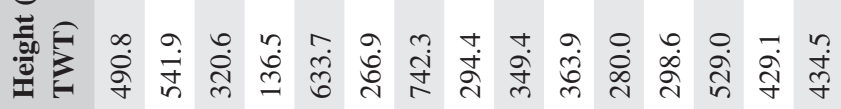

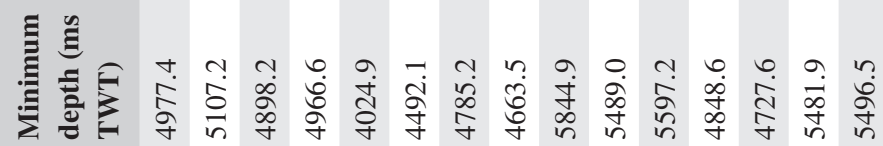

产

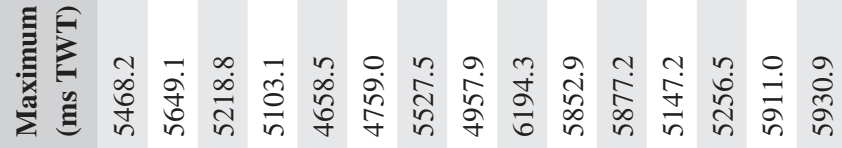

产产

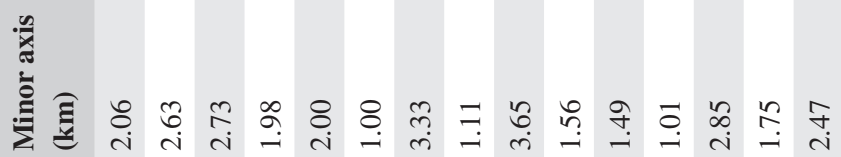

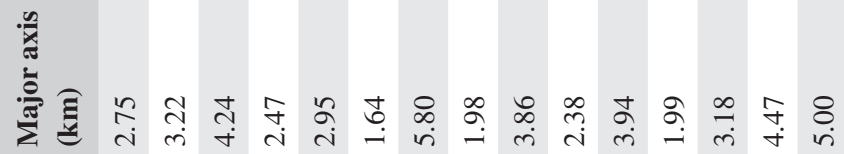

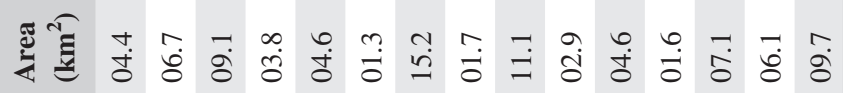

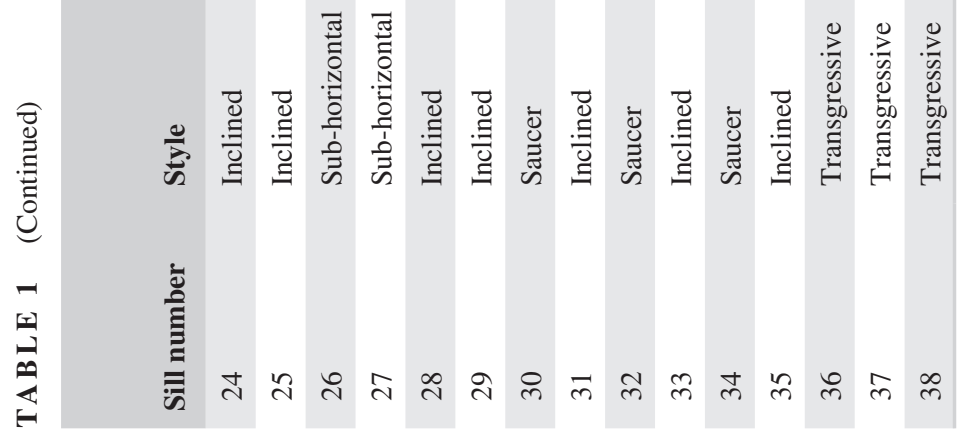



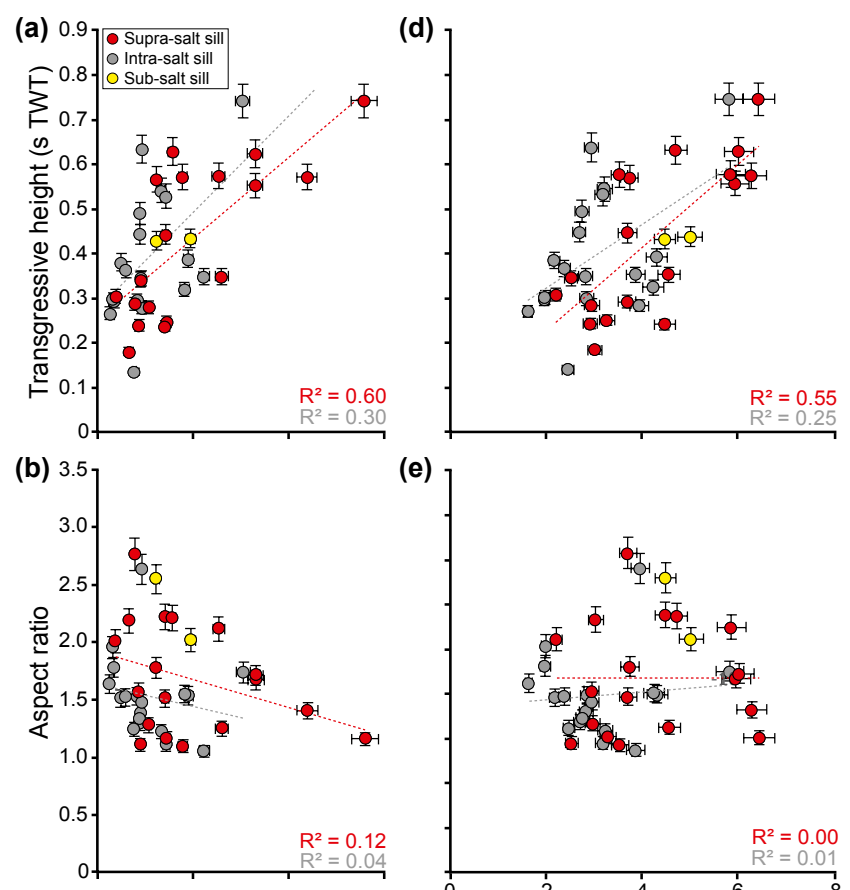

(e)
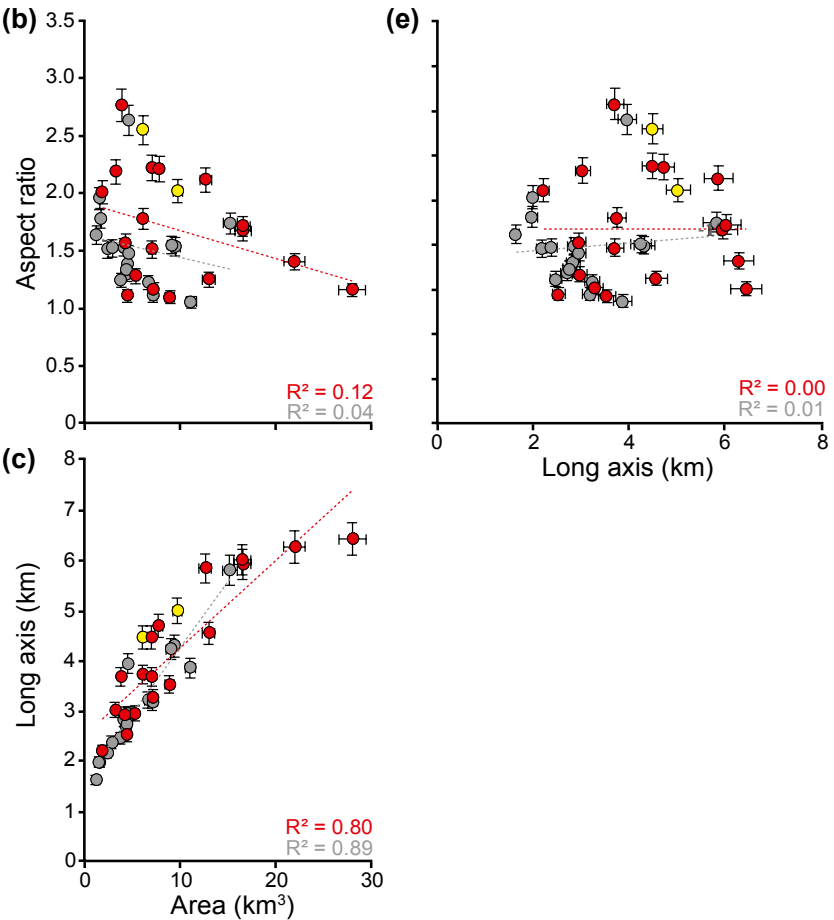

F I G U R E 9 Cross-plots of different sill geometrical parameters highlighting little difference between the structure of those intrusions below, within and above the salt

.55 respectively), as is the relationship between long axis and area $\left(R^{2}=.8\right)$; intra-salt intrusions display similar but typically weaker, positive trends $\left(R^{2}=.25-.89\right)$ (Figure 9a,c,d). Aspect ratios of both intra-and supra-salt sills show no correlation to area or long axis length $\left(R^{2}=.12\right.$; Figure $\left.9 \mathrm{~b}, \mathrm{e}\right)$.

\subsection{3 $\quad$ Structures spatially associated with intrusions}

Reflections immediately overlying the mapped intrusions are typically not locally folded (Figures 2 and 4). However, the strata above S4 and S5 are deformed into a ca. 6-km-wide, ca. $0.1 \mathrm{~s}$ TWT high, dome-shaped fold (e.g. Figure $4 \mathrm{~b}$ ). The reflection marking the top of this fold, located just above H2 (near Coniacian-Santonian boundary), truncates underlying reflections and is onlapped by overlying strata (e.g.
Figure 4b). This dome-shaped fold is superimposed onto a broader area (ca. $192 \mathrm{~km}^{2}$ ) of locally elevated relief expressed across $\mathrm{H} 2$ and $\mathrm{H} 3$ (near Top Santonian) above the Merluza Graben (Figures $4 b$ and 5b,c). Underlying this area of elevated relief are the supra-salt intrusions S2-S7, S9-S11 and S15. Strata between H3 and H6 (near Top Cretaceous) thin across this area of elevated relief (Figure 5d).

In the supra-salt strata above the Merluza Graben, we identify three vent-like structures (e.g. Figures $4 \mathrm{~b}$ and 8c). Two vent-like structures (V1 and V2) display a complex eyeshaped morphology; they are bound by convex-downwards bases, which truncate stratigraphic reflections, and irregular, convex-upwards tops that are onlapped by overlying strata (e.g. Figure 8c). The oldest of these vent-like structures (V1) is onlapped by $\mathrm{H} 2$ and cross-cut by the younger eye-shaped feature (V2), which is itself onlapped by intra-Santonian strata (e.g. Figure 8c). Seismic amplitude is variable across the surfaces bounding these eye-shaped structures, but is typically low and increases at the edges of the structures where they merge (e.g. Figure 8c). The upper surface reflections most commonly have a negative polarity, with rarer occurrences displaying a positive polarity (e.g. Figure 8c). Basal surface reflections are positive polarity (e.g. Figure 8c). Reflections within the eye-shaped structures also vary in amplitude, although they are typically low amplitude, and are chaotic (e.g. Figure $8 \mathrm{c}$ ). The third vent-like structure (V3) rests on directly on the lateral limit of the fold developed above S4 and S5 (Figure 4b). Unlike V1 and V2, V3 displays a conformable base onto which convex-upwards reflections downlap; the uppermost of the convex-upwards reflections is onlapped by overlying strata (Figure $4 b$ ).

\section{5 | DISCUSSION}

\section{$5.1 \quad$ Timing of salt tectonics}

Onlap of Albian-to-Santonian strata (including H1-H3) onto stocks, as well as ENE- to NE-trending walls and rollers, coupled with the presence of associated salt-detached growth faults, indicate salt movement started soon after its deposition in the Late Aptian-to-Early Albian (Figures 2 and 4). These seismic-stratigraphic observations are consistent with previous studies that linked Albian-to-Cenomanian salt deformation to gravity-driven, up-dip extension generated by margin tilting (Figures 1b,c and 2) (e.g. Davison et al., 2012; Demercian et al., 1993; Quirk et al., 2012). Halokinetic sequences observed in minibasins away from the Merluza Graben, and located between $\mathrm{H} 2$ (near Coniacian-Santonian boundary) and $\mathrm{H} 7$ (intra-Palaeogene), suggest adjacent stocks and walls rose as passive diapirs during the Late Cretaceous-to-Early Cenozoic (e.g. Figures 2 and 4) (e.g. Coleman et al., 2018). The presence of secondary welds and diapirs with tear-drop shaped 
cross-sectional geometries, coupled with folding and uplift of diapir roofs, indicates active diapir rise until the Neogene, and suggests deformation up-dip of the Merluza Graben was influenced by late-stage shortening (e.g. Figures 2 and 4c) (e.g. Coleman et al., 2018). Compared to elsewhere along the updip extensional domain, this late-stage shortening landwards of the Merluza Graben appears localized to our study area (e.g. Davison et al., 2012; Quirk et al., 2012).

In contrast to the extension- and contraction-driven growth of very large (up to ca. $3.2 \mathrm{~s}$ TWT tall) salt structures away from the Merluza Graben, the rollers above its bounding faults are ca. $1.2 \mathrm{~s}$ TWT tall and only display evidence of extension-driven, Albian-to-Campanian or Albianto-Neogene growth (Figures 2, 4 and 6); i.e. rollers above the Merluza Graben did not evolve into passive or subsequently active diapirs. Deformation of the rollers was preferentially accommodated by slip and rollover of overburden strata above associated normal faults, generally decreasing through time after its peak during the Santonian (Figures $4 \mathrm{~b}$ and 6). Furthermore, the relative increase in thickness of Albianto-Santonian growth strata above the northern sector of the Merluza Graben, compared to some other parts of the study area, suggests salt movement and accommodation generation were locally enhanced during this period (e.g. Figures 2, 4a and $5 \mathrm{e})$.

\section{2 | Timing of igneous activity}

A variety of igneous events have been recognized in the Santos Basin, including Early Cretaceous pre-rift and syn-rift magmatism, pre-salt volcanism and post-salt magmatic activity, which are mainly dated as 90-80 Ma (Santonian) and 60-40 Ma (Palaeocene-to-Eocene) (e.g. Fornero et al., 2019; Oreiro et al., 2008). Because boreholes do not intersect the igneous intrusions and associated extrusive features we map, we cannot constrain their emplacement age using radiometric techniques. However, we note that the presence of intrusions within a stratigraphic package indicates emplacement occurred during or after its deposition; i.e. borehole-derived biostratigraphic dates of strata hosting intrusions can thus be used to define the maximum emplacement age. To estimate the maximum emplacement age of intrusions hosted within the Cretaceous strata, we examined the youngest mapped stratigraphic horizon they cross-cut. For example, although S37 and S38 are primarily sub-salt, they transgress BS and their emplacement must therefore post-date salt deposition; i.e. magmatism occurred post-earliest Albian. Similarly, we identify one saucer-shaped sill (S1) emplaced above H2 (i.e. the near Coniacian-Santonian boundary) that terminates just below H3, near the Top Santonian, suggesting at least some magmatic activity occurred towards the end of the Santonian or later. By only assessing the age of the host rock encasing intrusions, we cannot determine whether all magmatic activity occurred simultaneously (e.g. towards the end of the Santonian), or if intrusion was incremental over a prolonged period of time (e.g. between the late Albian and end of the Santonian) (e.g. Magee et al., 2014; Reeves et al., 2018; Schofield et al., 2017; Trude et al., 2003).

To further constrain the age of magmatic activity, we note there is a dome-shaped fold developed directly above S4 and S5 (e.g. Figure 4b), which we suggest formed to accommodate the intruded magma volume; i.e. it is an intrusioninduced forced fold (e.g. Hansen \& Cartwright, 2006; Magee et al., 2013; Stearns, 1978; Trude et al., 2003). The top of this fold occurs just above $\mathrm{H} 2$, where it truncates underlying reflections and is onlapped by overlying, likely of the earliest Santonian strata (Figure 4b). These seismic-stratigraphic relationships indicate the top fold surface marked the synintrusion palaeosurface (cf. Trude et al., 2003), suggesting S4 and S5 were emplaced in the Santonian. The presence of stacked, convex-upwards reflections (V3) downlapping onto this folded horizon appear similar to volcanoes and fluid escape vents observed elsewhere, further supports our inference that the top fold marked a syn-intrusion palaeosurface (Figure 4b) (e.g. Hansen, 2006; Magee et al., 2013; Reynolds et al., 2018). As S1 occurs at a higher stratigraphic level than the Santonian reflections that onlap the forced fold, it is thus younger than S4 and S5 (Figure 8a).

We identify several eye-shaped structures within our data, which have tops located at and onlapped by different stratigraphic horizons; i.e. V1 is onlapped by H2, whereas V2 is onlapped by intra-Santonian strata (e.g. Figure 8c). These eye-shaped structures appear similar to hydrothermal vents observed in seismic reflection data elsewhere (e.g. Jamtveit et al., 2004; Magee et al., 2016; Planke et al., 2005; Svensen et al., 2003). If the eye-shaped structures mapped are related to magmatism in the study area, their development at different stratigraphic levels further implies igneous activity was punctuated. Overall, based on our seismic-stratigraphic observations, we suggest igneous activity likely initiated after salt deposition and the onset of salt movement, probably during the Albian to Turonian. Magmatism continued, albeit likely incrementally, to the late Santonian or later. Our inferred ages of igneous activity broadly coincide with a phase of widespread magmatism across the Santos and Campos basins at ca. 90-80 Ma (e.g. Oreiro et al., 2008); a magmatic event at this time is supported by the high percentage of altered basalt fragments within Santonian turbidite reservoirs across the Santos Basin (e.g. Klarner et al., 2008; Mohriak, 2003). With respect to the salt-related deformation history outlined above, Albian-to-Santonian magmatism implies intrusion occurred synchronous to gravity-driven salt tectonics (Figure 1b). 


\section{3 | Salt-magma interaction}

\subsubsection{Influence of salt on magma emplacement mechanics}

The geometry, size and distribution of igneous sheet intrusions are influenced by the physical behaviour of the host rock during magma emplacement (e.g. Eide et al., 2017; Gudmundsson, 2011; Kavanagh et al., 2006; Kavanagh \& Pavier, 2014; Magee et al., 2016; Schmiedel et al., 2017; Schmiedel et al., 2019; Schofield et al., 2014, 2012). Although sheet intrusions are typically considered to propagate via brittle tensile fracturing of host rock, several studies have demonstrated sill emplacement can also be facilitated by host rock fluidization, ductile flow and/or viscous indentation (e.g. Galland et al., 2019; Pollard et al., 1975; Schofield et al., 2012, 2014; Spacapan et al., 2017). For example, Schofield et al. (2014) showed mafic magma emplaced within the Werra salt complex (Herfa-Neurode mine, Germany) intruded via (e.g. Figure 10): (a) brittle fracturing within halite sequences, forming dykes; and (b) non-brittle, fluidization of sub-horizontal carnallite layers, where magma was emplaced as sills. These variations in intrusion geometry and emplacement mechanics likely reflect differences in the temperature-dependent behaviour of halite and carnalite; halite is anhydrous and melts at ca. $800^{\circ} \mathrm{C}$, whereas carnallite is hydrous and behaves as a viscous fluid when it dehydrates at ca. $140-170^{\circ} \mathrm{C}$ (Schofield et al., 2014). The thermal conductivity of halite $\left(6.1 \mathrm{~W} / \mathrm{m}^{\circ} \mathrm{C}^{-1}\right)$ and carnallite $\left(0.8 \mathrm{~W} / \mathrm{m}^{\circ} \mathrm{C}^{-1}\right)$ may also have affected magma emplacement mechanics as the rapid transfer of heat into rocks with high thermal conductivities will inhibit their melting (Schofield et al., 2014). Overall, it seems likely that salts with relatively high melting temperatures and thermal conductivities (e.g. halite, sylvite and anhydrite) will fracture during rapid (i.e. high strain rate) magma emplacement, whereas those with low dehydration temperatures and thermal conductivities (e.g. carnallite, epsomite, gypsum, bischofite and kieserite) may behave as a fluid during intrusion and thus deform in a non-brittle fashion (Schofield et al., 2014).

Due to a lack of borehole data, we do not know the composition or distribution of different evaporites within the salt structures mapped in our study area. Furthermore, seismic reflection data are unable to resolve the small-scale features (e.g. intrusion tip geometry) indicative of different magma emplacement processes (see Magee et al., 2019 and references therein). Despite these limitations in our data, we make several observations that may provide some insight into whether the syn-emplacement behaviour of the salt affected magma intrusion. We first note that many supra-salt intrusion reflections are characterized by arrays of subtle but abrupt, linear vertical offsets (e.g. Figures 2, $4 \mathrm{~b}$ and $8 a, b)$. These vertical offsets are oriented either parallel to the strike of inclined sheets, or saucer-shaped sill limbs (e.g. Figure $8 \mathrm{a}$ ), or are radially disposed around a deep portion of the intrusion (e.g. Figure 8b). Where similar vertical offsets have been observed in outcrop, structural relationships and petrofabric data reveal these features commonly develop in response to the formation, and potential coalescence, of vertically offset sheet segments during propagation (e.g. Magee et al., 2019; Walker, 2016). In contrast to the supra-salt sills, those emplaced within the salt are
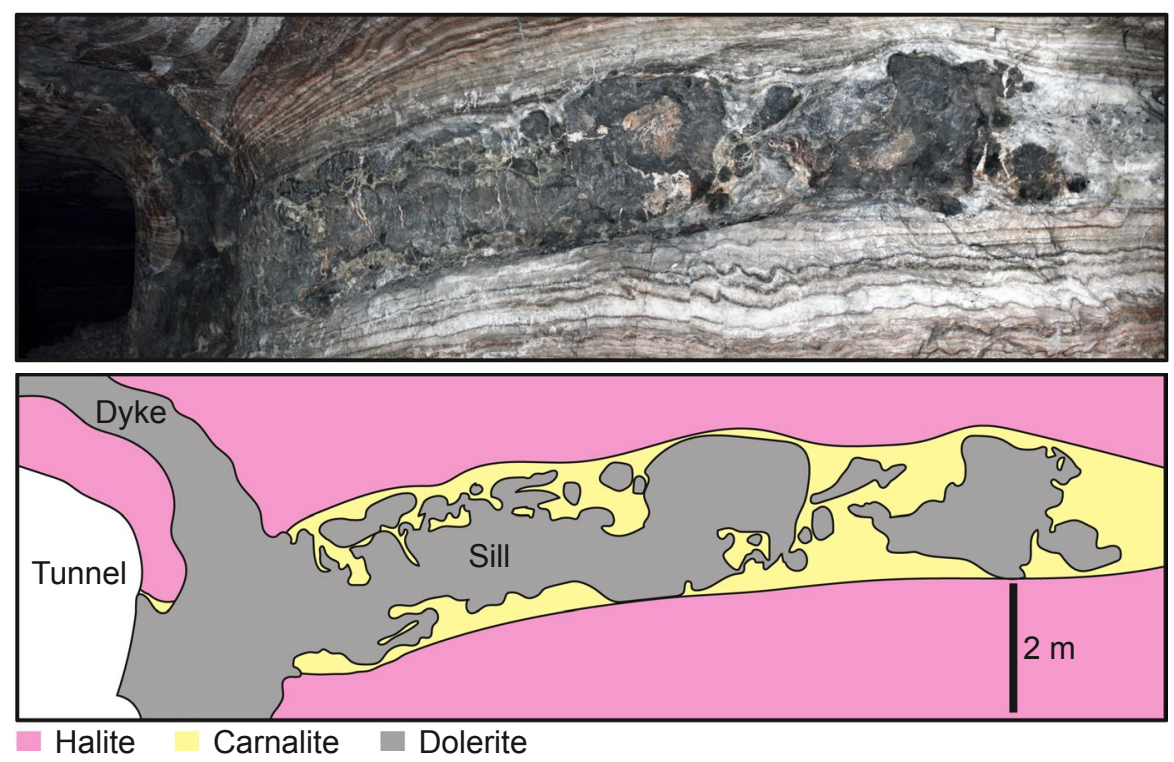

F I G U RE 10 Outcrop photograph (courtesy of Nick Schofield) and interpreted schematic showing salt-magma interactions in the Werra salt, Germany (redrawn from Schofield et al., 2014). The mafic magma intruded as dykes within halite, but fluidized carnallite layers where it formed sills (Schofield et al., 2014) 
expressed as apparently smoother reflections; i.e. they appear to contain relatively fewer, abrupt vertical offsets (e.g. Figures 2, 4a,b and 8). This smoother appearance of the intra-salt sills may imply that they were emplaced either as: (a) continuous (i.e. they were not segmented) sheets; or (b) closely spaced magma fingers, which tend to form (although not always) at the same structural level, in response to non-brittle deformation of the host salt rock (e.g. fluidization) (e.g. Galland et al., 2019; Pollard et al., 1975; Schofield et al., 2010).

We do not have the hard rock data to test our speculations, but the apparent variation in reflection smoothness between the intra- and supra-salt sills suggest the differences in their respective host rock may have influenced emplacement mechanics (e.g. Eide et al., 2017). Although we postulate intra- and supra-salt sill emplacement may have been mechanically different, all intrusion populations are geometrically similar (Figure 9). This lack of geometrical variation across the intrusions suggests their size may have been primarily controlled by emplacement depth and stress conditions, as opposed to the host rock lithology (e.g. Fialko \& Simons, 2001; Menand, 2011; Pollard \& Johnson, 1973).

\subsection{2 | Influence of salt on magma distribution}

Intra-salt intrusions, including those clustered above the Merluza Graben and its western bounding fault, are observed in the salt where it is relatively thin (ca. $<1 \mathrm{~s}$ TWT thick), typically $<0.5 \mathrm{~s}$ TWT thick (Figures $2,4,7 \mathrm{~d}$ and 8). Diapirs $>1.5 \mathrm{~s}$ TWT thick appear to lack intrusions within them, although some intra-salt sills are observed close to their flanks (Figures 2, 4c and 7d). This apparent absence of intrusions in the large salt structures may be real, or it may reflect that sub-horizontally emplaced sills were rotated to steeper dips during diapir growth, inhibiting their imaging by seismic reflection data. Most supra-salt intrusions are interconnected (i.e. they form a sill complex) and occur within and along the Merluza Graben, where the underlying salt is relatively thin (ca. $<1 \mathrm{~s}$ TWT thick), away from areas containing intra-salt sills (e.g. Figure 7). Apparent clustering of the intra- and supra-salt intrusions, as well as sub-salt sills, implies that Albian-to-Santonian magma ascent through sub-salt strata was localized within the preexisting Merluza Graben (Figure 7d). This is consistent with observations from elsewhere in the Santos Basin that suggest prerift structures influenced melt ascent and the overall distribution of post-rift magmatism (e.g. Mohriak et al., 1995; Oreiro et al., 2008). We also show that intrusions emplaced within the salt rarely fed supra-salt sills or inclined sheets. Because the supra-salt sills above the Merluza Graben do not appear to be fed by intra-salt sills (e.g. Figure 7d), we suggest they were likely fed by (sub-) vertical dykes, which are not imaged by our seismic reflection data (e.g. Eide et al., 2018; Magee \& Jackson, 2020; Malehmir et al., 2018). The absence of intra-salt sills where such possible feeder dykes may be expected to cross-cut the salt, i.e. beneath overlying sills, would indicate emplacement conditions locally favoured magma ascent directly through the salt. We suggest bypassing of the salt during magma ascent may have occurred because the evaporites are locally dominated by halite (e.g. units A1 or A3; Rodriguez et al., 2018), which can fracture in response to the types of high strain that likely accommodate dyking (Schofield et al., 2014). Conversely, we suggest that where the salt contains, or contained, evaporites with low dehydration temperatures and thermal conductivities, such as carnallite (e.g. units A2 or A4; Rodriguez et al., 2018), space generated by dehydration reaction during emplacement favoured sill formation and arrested magma ascent (Schofield et al., 2014).

\subsubsection{Influence of magmatism on the tectono- stratigraphic development of salt basins}

We show that Albian-to-Santonian magmatism coincided with the main phase of salt movement (Figures 2 and 4). At this time, localized growth of Albian-to-Santonian strata towards the extensional rollovers above the Merluza Graben accommodated more deformation in the area relative to the rise of neighbouring walls and diapirs; i.e. suggesting salt flow and related deformation was greatest where magma was being emplaced (Figures 2-4, 7 and 11). Albian-toSantonian salt movement above the Merluza Graben may have been instigated by (Figure 11a,b): (a) the presence of an inherited base-salt low, containing thicker, more halite-rich, and thus more mobile salt than adjacent areas (e.g. Dooley et al., 2017, 2020; Pichel et al., 2019; Pichel et al., 2019); and/or (b) heat-enhanced salt flow driven by igneous activity within the Merluza Graben (see López-García et al., 2020; Schofield et al., 2014; Underhill, 2009).

In addition to the potential role of magmatism in driving salt movement, we identify an anomalous area of elevated structural relief expressed at $\mathrm{H} 2$ (near Coniacian-Santonian boundary) and H3 (near Top Santonian) above the suprasalt sill complex in the Merluza Graben (e.g. Figures $4 \mathrm{~b}$ and $5 \mathrm{~b}, \mathrm{c})$. This zone of uplift corresponds to a NW-trending antiform and occurs within the shared footwall of the two, NESE striking, outward-dipping, salt-detached faults overlying a top-salt low above the Merluza Graben (e.g. Figures $4 b$ and $5 b, c)$. Strata between H1 (near Cenomanian-Turonian boundary) and $\mathrm{H} 3$ thicken across this antiform, whereas strata bound by $\mathrm{H} 3$ and H6 (near Top Cretaceous) thins across the structure (Figure 5e,f). Our observations suggest 
W
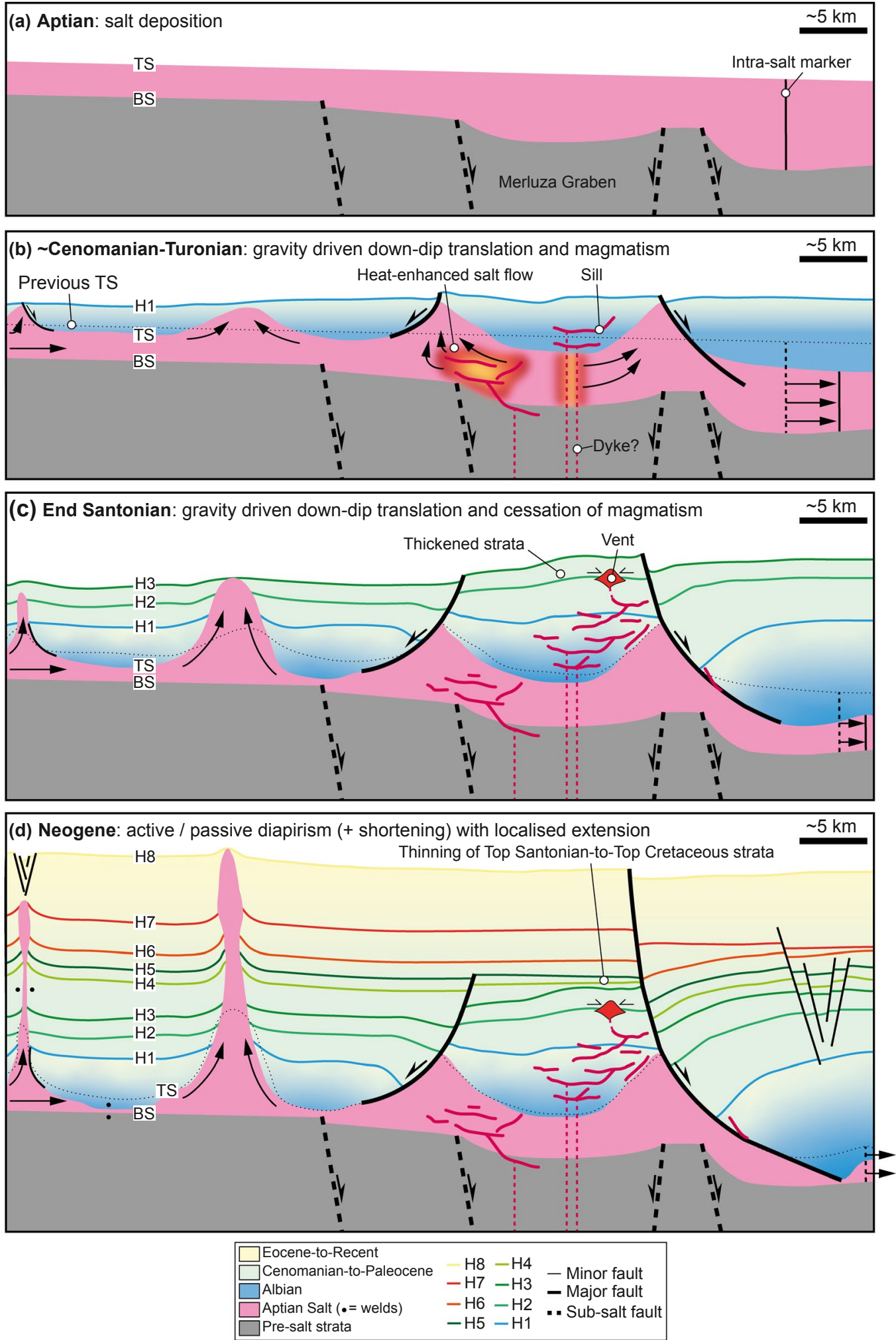

FIG URE 11 Schematics showing the possible salt tectonic and magmatic evolution of the study area. (a) In the Aptian, salt was deposited over a rugged topography, including the pre-salt Merluza Graben. (b) Near the Cenomanian-Turonian boundary, after salt deposition, salt flow towards the east led to passive diapirism and development of rollers in the study area; the rollers occur in the footwall of extensional, salt-detached faults located above the boundaries of the Merluza Graben. Magmatism above the Merluza Graben produced discrete intra- and supra-salt sill complexes. (c) At the end Santonian, magmatism had ceased, resulting in a crystallized rigid framework of intrusions within the salt and younger Cretaceous strata above the Merluza Graben. (d) In the Cenozoic, until the Neogene, salt kinematics up-dip of the Merluza Graben was locally characterized by shortening and active diapirism, produced teardrop-shaped salt bodies. Extension continued above the Merluza Graben on the eastdipping salt-detached fault. (d). General section structure based on Figure 2a 
this thickening of the Albian-to-Santonian sedimentary sequence may be attributed to the local occurrence of multiple sills within the succession (e.g. Figure 4b), some of which may not be resolved in our seismic reflection data (e.g. Schofield et al., 2017). Specifically, we propose that the cumulative sill thickness was spatially accommodated, at least partly, by roof uplift and/or floor subsidence and thereby increasing the vertical separation between $\mathrm{H} 1$ and H3 (Figure 11c) (Mark et al., 2019). We also suggest this local over-thickening of the Albian-to-Santonian sedimentary sequence was expressed at the free surface as an area of elevated relief, across which strata within the H3-H6 succession thinned during its deposition.

Post-Santonian (i.e. post-intrusion) salt-induced deformation can be sub-divided into two distinct structural domains in our study area: (a) west of the Merluza Graben where the salt, resting on a relatively undeformed terrace, rose diapirically by passive processes, followed by late-stage, Cenozoic shortening and active rise (e.g. Figures 2, 3a and 11d); and (b) above the Merluza Graben, where diapirism was driven by continued, albeit decreasing, extension on salt-detached listric normal faults and limited diapiric salt rise (e.g. Figures 2, 3a, 4b, 6 and 11d). This post-Santonian strain partition, with up-dip shortening and coeval down-dip extension, coupled with significant variations in the degree of salt rise, could in places be attributed to welding of the salt layer between the up-dip diapirs. However, such welding could not explain the strain partition in areas where the salt layer is still relatively thick (ca. $>200$ ms TWT) and, thus, updip diapirs are still connected with the salt structures down-dip in the Merluza Graben (e.g. Figure 2b). Alternatively, strain partitioning may have been driven by base-salt relief within the presalt Merluza Graben as its western shoulder could have acted as a local barrier to basin-ward salt flow and promoted mild up-dip shortening, similar to other areas in the Santos Basin (Dooley et al., 2020; Pichel et al., 2019; Pichel et al., 2019). However, it is unclear why graben-related buttressing would have led to strain partitioning in the post-Santonian, after most salt had been evacuated from beneath the minibasins, and not before (Jackson \& Hudec, 2017; Peel, 2014; Pichel et al., 2018). Postintrusion salt movement could also be restricted by (Schofield et al., 2014): (a) the presence of mechanically strong crystalline intrusions within the salt, forming a rigid framework that buttressed salt movement; and (b) the syn-intrusion dehydration of weak evaporite layers (e.g. gypsum and carnallite), which commonly lubricate salt movement, compared to stronger counterparts, such as anhydrite and halite (e.g. Jackson \& Hudec, 2017; Urai et al., 1986; Van Keken et al., 1993).

\section{6 | CONCLUSIONS}

Salt tectonics and magmatism are prevalent in many sedimentary basins worldwide. It is thus inevitable that, in some places, magma will interact with salt as it ascends towards the surface. We use 3D seismic reflection data from the Santos Basin, offshore Brazil to examine the interactions between igneous sheet intrusions emplaced below, within and above an Aptian salt layer. Sills are geometrically similar regardless of whether they were emplaced below, within or above the salt, although those within the salt intrusion are characterized by smoother reflections. We also observe intra-salt and supra-salt sill clusters to be laterally offset and not linked. We suggest some areas of the salt captured ascending magma, perhaps because they contained hydrous salts that favoured sill emplacement, whereas other areas were bypassed by dyke intrusion. Mapping of salt structures and halokinetic sequences reveals salt movement began in the Albian-to-Santonian due to gravity-driven extension. This Albian-to-Santonian phase of salt movement was primarily focused above the pre-salt Merluza Graben where salt rollers developed with listric normal faults in the sedimentary cover. Seismic-stratigraphic analyses of onlaps onto intrusion-induced forced folds and vents indicates sill emplacement, which was focused above the Merluza Graben, coincided with this Albianto-Santonian phase of salt movement. Post-Santonian salt movement above the Merluza Graben continued via extensional roll-over with little salt rise, albeit at a decreased rate, but elsewhere was dominated by active and/or passive diapir ascent. We suggest the intrusion of hot magma enhanced salt flow during the Albian-to-Santonian, localizing salt movement above the Merluza Graben, but upon crystallization formed a rigid intrusive framework within the salt that inhibited Post-Santonian salt rise. Overall, our results suggest salt--magma interactions influenced magma emplacement mechanics and intrusion distribution, whereas the presence of hot magma and crystallized intrusions within the salt impacted salt tectonics.

\section{ACKNOWLEDGEMENTS}

We are grateful to ANP for providing and permitting us to publish the seismic reflection data and to Schlumberger for the interpretation software. We thank Imperial College London UROP scheme for funding AM-N in the initial phase of this work. We are grateful to Christian Eide and Nick Schofield for their constructive reviews and to Atle Rotevatn for the editorial handling.

\section{CONFLICT OF INTEREST}

The authors declare there are no conflicts of interest.

\section{Peer Review}

The peer review history for this article is available at https:// publons.com/publon/10.1111/bre.12537.

\section{DATA AVAILABILITY STATEMENT}

The seismic reflection data that support the findings of this study are available from ANP but restrictions apply to the availability of these data, which were used under a 
confidentiality agreement for the current study, and so are not publicly available.

\section{ORCID}

Craig Magee (iD https://orcid.org/0000-0001-9836-2365

Christopher A.-L. Jackson (D) https://orcid.

org/0000-0002-8592-9032

\section{REFERENCES}

Bally, A. (1981). Thoughts on the tectonics of folded belts. In K. McClay \& N. Price (Eds.), Thrust and nappe tectonics (Vol. 9, pp. 13-32). Geological Society, London, Special Publications.

Barton, M. D., \& Johnson, D. A. (1996). Evaporitic-source model for igneous-related $\mathrm{Fe}$ oxide-(REE-Cu-Au-U) mineralization. Geology, 24(3), 259-262. https://doi.org/10.1130/00917613(1996)024<0259:ESMFIR>2.3.CO;2

Bedard, J. H., Naslund, H. R., Nabelek, P., Winpenny, A., Hryciuk, M., Macdonald, W., Hayes, B., Steigerwaldt, K., Hadlari, T., Rainbird, R., Dewing, K., \& Girard, E. (2012). Fault-mediated melt ascent in a Neoproterozoic continental flood basalt province, the Franklin sills, Victoria Island, Canada. Geological Society of America Bulletin, 124(5-6), 723-736. https://doi.org/10.1130/ B30450.1

Blažić, L., \& Moreau, J. (2017). Discovery of Lower Cretaceous hydrothermal vent complexes in a late rifting setting, southern North Sea: Insights from 3D imaging. Journal of the Geological Society, 174(2), 233-241. https://doi.org/10.1144/jgs2015-155

Brown, A. R. (2011). Interpretation of three-dimensional seismic data (6th ed., Vol. 42). AAPG and SEG.

Brun, J.-P., \& Mauduit, T.-P.-O. (2009). Salt rollers: Structure and kinematics from analogue modelling. Marine and Petroleum Geology, 26(2), 249-258. https://doi.org/10.1016/j.marpetgeo.2008.02.002

Coleman, A. J., Jackson, C. A. L., Duffy, O. B., \& Nikolinakou, M. A. (2018). How, where, and when do radial faults grow near salt diapirs? Geology, 46(7), 655-658.

Davison, I., Anderson, L., \& Nuttall, P. (2012). Salt deposition, loading and gravity drainage in the Campos and Santos salt basins. In G. Alsop, S. Archer, A. Hartley, N. T. Grant \& R. Hodgkinson (Eds.), Salt tectonics, sediments, and prospectivity (Vol. 363, pp. 159-174). Geological Society. London, Special Publications.

Demercian, S., Szatmari, P., \& Cobbold, P. (1993). Style and pattern of salt diapirs due to thin-skinned gravitational gliding, Campos and Santos basins, offshore Brazil. Tectonophysics, 228(3-4), 393-433. https://doi.org/10.1016/0040-1951(93)90351-J

Dooley, T. P., Hudec, M. R., Carruthers, D., Jackson, M. P., \& Luo, G. (2017). The effects of base-salt relief on salt flow and suprasalt deformation patterns-Part 1: Flow across simple steps in the base of salt. Interpretation, 5(1), SD1-SD23. https://doi.org/10.1190/ INT-2016-0087.1

Dooley, T. P., Hudec, M. R., Pichel, L. M., \& Jackson, M. P. (2020). The impact of base-salt relief on salt flow and suprasalt deformation patterns at the autochthonous, paraautochthonous and allochthonous level: Insights from physical models. In K. McClay \& J. Hammerstein (Eds.), Passive margins: Tectonics, sedimentation and magmatism (Vol. 476, pp. 287-315). Geological Society, London, Special Publications.

Duarte, C. S., \& Viana, A. R. (2007). Santos Drift System: Stratigraphic organization and implications for late Cenozoic palaeocirculation in the Santos Basin, SW Atlantic Ocean. In A. Viana \& M. Rebesco (Eds.), Economic and palaeoceanographic significant of contourite deposits (Vol. 276, pp. 171-198). Geological Society, London, Special Publications.

Eide, C. H., Schofield, N., Jerram, D. A., \& Howell, J. A. (2017). Basinscale architecture of deeply emplaced sill complexes: Jameson Land, East Greenland. Journal of the Geological Society, 174, 23 40. https://doi.org/10.1144/jgs2016-018

Eide, C. H., Schofield, N., Lecomte, I., Buckley, S. J., \& Howell, J. A. (2018). Seismic interpretation of sill-complexes in sedimentary basins: The 'sub-sill imaging problem'. Journal of the Geological Society, 175, 193-209.

Fialko, Y., Khazan, Y., \& Simons, M. (2001). Deformation due to a pressurized horizontal circular crack in an elastic half-space, with applications to volcano geodesy. Geophysical Journal International, 146(1), 181-190. https://doi.org/10.1046/j.1365-246X.2001.00452.x

Fornero, S. A., Marins, G. M., Lobo, J. T., Freire, A. F. M., \& de Lima, E. F. (2019). Characterization of subaerial volcanic facies using acoustic image logs: Lithofacies and log-facies of a lava-flow deposit in the Brazilian pre-salt, deepwater of Santos Basin. Marine and Petroleum Geology, 99, 156-174. https://doi.org/10.1016/j. marpetgeo.2018.09.029

Galland, O., Spacapan, J. B., Rabbel, O., Mair, K., Soto, F. G., Eiken, T., Schiuma, M., \& Leanza, H. A. (2019). Structure, emplacement mechanism and magma-flow significance of igneous fingersImplications for sill emplacement in sedimentary basins. Journal of Structural Geology, 124, 120-135. https://doi.org/10.1016/ j.jsg.2019.04.013

Giles, K. A., \& Rowan, M. G. (2012). Concepts in halokinetic-sequence deformation and stratigraphy. In G. Alsop, S. Archer, A. Hartley, N. T. Grant \& R. Hodgkinson (Eds.), Salt tectonics, sediments and prospectivity (Vol. 363, pp. 7-31). Geological Society. London, Special Publications.

Gudmundsson, A. (2011). Deflection of dykes into sills at discontinuities and magma-chamber formation. Tectonophysics, 500(1-4), 50 64. https://doi.org/10.1016/j.tecto.2009.10.015

Guerra, M. C., \& Underhill, J. R. (2012). Role of halokinesis in controlling structural styles and sediment dispersal in the Santos Basin, offshore Brazil. In G. Alsop, S. Archer, A. Hartley, N. T. Grant \& R. Hodgkinson (Eds.), Salt tectonics, sediments, and prospectivity (Vol. 363, pp. 175-206). Geological Society. London, Special Publications.

Hansen, D. M. (2006). The morphology of intrusion-related vent structures and their implications for constraining the timing of intrusive events along the NE Atlantic margin. Journal of the Geological Society, 163, 789-800. https://doi.org/10.1144/0016-76492004-167

Hansen, D. M., \& Cartwright, J. (2006). The three-dimensional geometry and growth of forced folds above saucer-shaped igneous sills. Journal of Structural Geology, 28(8), 1520-1535. https://doi. org/10.1016/j.jsg.2006.04.004

Heimdal, T. H., Callegaro, S., Svensen, H. H., Jones, M. T., Pereira, E., \& Planke, S. (2019). Evidence for magma-evaporite interactions during the emplacement of the Central Atlantic Magmatic Province (CAMP) in Brazil. Earth and Planetary Science Letters, 506, 476492. https://doi.org/10.1016/j.epsl.2018.11.018

Holford, S. P., Schofield, N., MacDonald, J. D., Duddy, I. R., \& Green, P. F. (2012). Seismic analysis of igneous systems in sedimentary basins and their impacts on hydrocarbon prospectivity: Examples from the southern Australian margin. APPEA Journal, 52, 23. https://doi. org/10.1071/AJ11017 
Hudec, M. R., \& Jackson, M. (2007). Terra infirma: Understanding salt tectonics. Earth-Science Reviews, 82(1), 1-28. https://doi. org/10.1016/j.earscirev.2007.01.001

Iacono-Marziano, G., Ferraina, C., Gaillard, F., Di Carlo, I., \& Arndt, N. T. (2017). Assimilation of sulfate and carbonaceous rocks: Experimental study, thermodynamic modeling and application to the Noril'sk-Talnakh region (Russia). Ore Geology Reviews, 90, 399-413. https://doi.org/10.1016/j.oregeorev.2017.04.027

Jackson, C.-A.-L., Jackson, M. P., \& Hudec, M. R. (2015). Understanding the kinematics of salt-bearing passive margins: A critical test of competing hypotheses for the origin of the Albian Gap, Santos Basin, offshore Brazil. Geological Society of America Bulletin, 127(11-12), 1730-1751. https://doi.org/10.1130/ B31290.1

Jackson, C.-A.-L., Jackson, M. P., Hudec, M. R., \& Rodriguez, C. R. (2015). Enigmatic structures within salt walls of the Santos BasinPart 1: Geometry and kinematics from 3D seismic reflection and well data. Journal of Structural Geology, 75, 135-162. https://doi. org/10.1016/j.jsg.2015.01.010

Jackson, M. (1995). Retrospective salt tectonics. In M. Jackson, D. Roberts \& S. Snelson (Eds.), Salt tectonics: A global perspective (Vol. 65, pp. 1-28). AAPG Memoir.

Jackson, M. P., \& Hudec, M. R. (2017). Salt tectonics: Principles and practice. Cambridge University Press.

Jamtveit, B., Svensen, H., Podladchikov, Y. Y., \& Planke, S. (2004). Hydrothermal vent complexes associated with sill intrusions in sedimentary basins. In C. Breitkreuz \& N. Petford (Eds.), Physical geology of high-level magmatic systems (Vol. 234, pp. 233-241).

Karner, G., \& Gambôa, L. (2007). Timing and origin of the South Atlantic pre-salt sag basins and their capping evaporites. In B. Schreiber, S. Lugli \& M. Babel (Eds.), Evaporites through space and time (Vol. 285, pp. 15-35). Geological Society, London, Special Publications.

Kavanagh, J. L., Menand, T., \& Sparks, R. S. J. (2006). An experimental investigation of sill formation and propagation in layered elastic media. Earth and Planetary Science Letters, 245(3-4), 799-813. https://doi.org/10.1016/j.epsl.2006.03.025

Kavanagh, J. L., \& Pavier, M. J. (2014). Rock interface strength influences fluid-filled fracture propagation pathways in the crust. Journal of Structural Geology, 63, 68-75. https://doi.org/10.1016/ j.jsg.2014.03.001

Klarner, S., Ujetz, B., \& Fontana, R. L. (2008). Enhanced depositional and AVO models for lithologically complex sandstones in the Santos Basin, offshore Brazil. Petroleum Geoscience, 14(3), 235-243. https://doi.org/10.1144/1354-079308-760

Li, C., Ripley, E. M., Naldrett, A. J., Schmitt, A. K., \& Moore, C. H. (2009). Magmatic anhydrite-sulfide assemblages in the plumbing system of the Siberian Traps. Geology, 37(3), 259-262. https://doi. org/10.1130/G25355A.1

López-García, J. M., Moreira, D., Benzerara, K., Grunewald, O., \& LópezGarcía, P. (2020). Origin and evolution of the halo-volcanic complex of Dallol: Proto-volcanism in Northern Afar (Ethiopia). Frontiers in Earth Science, 7, 351. https://doi.org/10.3389/feart.2019.00351

Magee, C., Briggs, F., \& Jackson, C.-A.-L. (2013). Lithological controls on igneous intrusion-induced ground deformation. Journal of the Geological Society, 170(6), 853-856. https://doi.org/10.1144/jgs20 13-029

Magee, C., Duffy, O. B., Purnell, K., Bell, R. E., Jackson, C. A. L., \& Reeve, M. T. (2016). Fault-controlled fluid flow inferred from hydrothermal vents imaged in 3D seismic reflection data, offshore NW
Australia. Basin Research, 28(3), 299-318. https://doi.org/10.1111/ bre. 12111

Magee, C., Hunt-Stewart, E., \& Jackson, C. A. L. (2013). Volcano growth mechanisms and the role of sub-volcanic intrusions: Insights from 2D seismic reflection data. Earth and Planetary Science Letters, 373, 41-53. https://doi.org/10.1016/j.eps1.2013.04.041

Magee, C., \& Jackson, C.-L. (2020). Seismic reflection data reveal the 3D structure of the newly discovered Exmouth Dyke Swarm, offshore NW Australia. Solid Earth, 11(2), 576-606.

Magee, C., Jackson, C. L., \& Schofield, N. (2014). Diachronous subvolcanic intrusion along deep-water margins: Insights from the Irish Rockall Basin. Basin Research, 26(1), 85-105. https://doi. org/10.1111/bre.12044

Magee, C., Maharaj, S. M., Wrona, T., \& Jackson, C.-A.-L. (2015). Controls on the expression of igneous intrusions in seismic reflection data. Geosphere, 11(4), 1024-1041. https://doi.org/10.1130/ GES01150.1

Magee, C., Muirhead, J. D., Karvelas, A., Holford, S. P., Jackson, C. A. L., Bastow, I. D., Schofield, N., Stevenson, C. T. E., McLean, C., McCarthy, W., \& Shtukert, O. (2016). Lateral magma flow in mafic sill complexes. Geosphere, 12(3), 809-841. https://doi.org/10.1130/ GES01256.1

Magee, C., Muirhead, J., Schofield, N., Walker, R. J., Galland, O., Holford, S., Spacapan, J., Jackson, C.-L., \& McCarthy, W. (2019). Structural signatures of igneous sheet intrusion propagation. Journal of Structural Geology, 125, 148-154. https://doi.org/10.1016/ j.jsg.2018.07.010

Malehmir, A., Bergman, B., Andersson, B., Sturk, R., \& Johansson, M. (2018). Seismic imaging of dyke swarms within the SorgenfreiTornquist Zone (Sweden) and implications for thermal energy storage. Solid Earth, 9(6), 1469-1485. https://doi.org/10.5194/ se-9-1469-2018

Mark, N., Schofield, N., Gardiner, D., Holt, L., Grove, C., Watson, D., Alexander, A., \& Poore, H. (2019). Overthickening of sedimentary sequences by igneous intrusions. Journal of the Geological Society, 176(1), 46-60. https://doi.org/10.1144/jgs2018-112

Meisling, K. E., Cobbold, P. R., \& Mount, V. S. (2001). Segmentation of an obliquely rifted margin, Campos and Santos basins, southeastern Brazil. AAPG Bulletin, 85(11), 1903-1924.

Menand, T. (2011). Physical controls and depth of emplacement of igneous bodies: A review. Tectonophysics, 500(1), 11-19. https://doi. org/10.1016/j.tecto.2009.10.016

Modica, C. J., \& Brush, E. R. (2004). Postrift sequence stratigraphy, paleogeography, and fill history of the deep-water Santos Basin, offshore southeast Brazil. AAPG Bulletin, 88(7), 923-945. https://doi. org/10.1306/01220403043

Mohriak, W. (2003). Bacias sedimentares da margem continental Brasileira (Vol. 3). CPRM Brasília.

Mohriak, W., Macedo, J., Castellani, R., Rangel, H., Barros, A., Latgé, M., Rizzo, J. (1995). Salt tectonics and structural styles in the deepwater province of the Cabo Frio region, Rio de Janeiro, Brazil. In M. Jackson, D. Roberts \& S. Snelson (Eds.), Salt tectonics: A global perspective (Vol. 65, pp. 273-304). AAPG Memoir: American Association of Petroleum Geologists.

Mohriak, W., Nóbrega, M., Odegard, M., Gomes, B., \& Dickson, W. (2010). Geological and geophysical interpretation of the Rio Grande Rise, south-eastern Brazilian margin: Extensional tectonics and rifting of continental and oceanic crusts. Petroleum Geoscience, 16, 231-245. https://doi.org/10.1144/1354-07930 9-910 
Mohriak, W., Szatmari, P., \& Anjos, S. M. C. (2009). Sal: Geologia e Tectônica; Exemplos nas Bacias Brasileiras. Terrae Didatica, 4(1), 90-91.

Oreiro, S. G., Cupertino, J. A., Szatmari, P., \& Filho, A. T. (2008). Influence of pre-salt alignments in post-Aptian magmatism in the Cabo Frio High and its surroundings, Santos and Campos basins, SE Brazil: An example of non-plume-related magmatism. Journal of South American Earth Sciences, 25(1), 116-131. https://doi. org/10.1016/j.jsames.2007.08.006

Pang, K.-N., Arndt, N., Svensen, H., Planke, S., Polozov, A., Polteau, S., Iizuka, Y., \& Chung, S.-L. (2013). A petrologic, geochemical and $\mathrm{Sr}-\mathrm{Nd}$ isotopic study on contact metamorphism and degassing of Devonian evaporites in the Norilsk aureoles, Siberia. Contributions to Mineralogy and Petrology, 165(4), 683-704. https://doi. org/10.1007/s00410-012-0830-9

Peel, F. J. (2014). The engines of gravity-driven movement on passive margins: Quantifying the relative contribution of spreading vs. gravity sliding mechanisms. Tectonophysics, 633, 126-142.

Pequeno, M. A. (2009). Albian/Maastrichtian tectono-stratigraphic evolution of central Santos Basin, offshore Brazil. (Masters). University of Texas at Austin.

Peron-Pinvidic, G., \& Manatschal, G.; a. t. I. R. W. Participants. (2019). Rifted margins: State of the art and future challenges. Frontiers in Earth Science, 7, 8. https://doi.org/10.3389/feart.2019.00218

Pichel, L., Finch, E., \& Gawthorpe, R. (2019). The impact of pre-salt rift topography on salt tectonics: A discrete-element modeling approach. Tectonics, 38(4), 1466-1488. https://doi.org/10.1029/2018T $\mathrm{C} 005174$

Pichel, L., \& Jackson, C.-L. (2020). Four-dimensional variability of composite halokinetic sequences. Basin Research, 32, 1277-1299. https://doi.org/10.1111/bre.12428

Pichel, L. M., Jackson, C. A. L., Peel, F., \& Dooley, T. P. (2019). Basesalt relief controls salt-tectonic structural style, São Paulo Plateau, Santos Basin, Brazil. Basin Research, 32, 453-484. https://doi. org/10.1111/bre.12375

Pichel, L. M., Peel, F., Jackson, C. A., \& Huuse, M. (2018). Geometry and kinematics of salt-detached ramp syncline basins. Journal of Structural Geology, 115, 208-230.

Planke, S., Rasmussen, T., Rey, S. S., \& Myklebust, R. (2005). Seismic characteristics and distribution of volcanic intrusions and hydrothermal vent complexes in the Vøring and Møre basins. In A. G. Doré (Ed.), Petroleum Geology: North-West Europe and Global Perspectives - Proceedings of the 6th Petroleum Geology Conference (pp. 833-844). Geological Society.

Pollard, D. D., \& Johnson, A. M. (1973). Mechanics of growth of some laccolithic intrusions in the Henry Mountains, Utah, II: Bending and failure of overburden layers and sill formation. Tectonophysics, 18(3), 311-354. https://doi.org/10.1016/0040-1951(73)90051-6

Pollard, D. D., Muller, O. H., \& Dockstader, D. R. (1975). The form and growth of fingered sheet intrusions. Geological Society of America Bulletin, 86(3), 351-363. https://doi.org/10.1130/00167606(1975)86<351:TFAGOF>2.0.CO;2

Quirk, D. G., Schødt, N., Lassen, B., Ings, S. J., Hsu, D., Hirsch, K. K., \& Von Nicolai, C. (2012). Salt tectonics on passive margins: examples from Santos, Campos and Kwanza basins. In G. Alsop, S. Archer, A. Hartley, N. T. Grant \& R. Hodgkinson (Eds.), Salt deposition, loading and gravity drainage in the Campos and Santos salt basins (Vol. 363, pp. 207-244). Geological Society. London, Special Publications.
Reeves, J., Magee, C., \& Jackson, C. A. L. (2018). Unravelling intrusion-induced forced fold kinematics and ground deformation using 3D seismic reflection data. Volcanica, 1(1), 1-17. https://doi. org/10.30909/vol.01.01.0117

Reynolds, P., Schofield, N., Brown, R. J., \& Holford, S. P. (2018). The architecture of submarine monogenetic volcanoes-insights from 3D seismic data. Basin Research, 30, 437-451. https://doi.org/10.1111/ bre. 12230

Ripley, E. M., Lightfoot, P. C., Li, C., \& Elswick, E. R. (2003). Sulfur isotopic studies of continental flood basalts in the Noril'sk region: Implications for the association between lavas and ore-bearing intrusions. Geochimica Et Cosmochimica Acta, 67(15), 2805-2817. https://doi.org/10.1016/S0016-7037(03)00102-9

Rodriguez, C., Jackson, C.-L., Rotevatn, A., Bell, R., \& Francis, M. (2018). Dual tectonic-climatic controls on salt giant deposition in the Santos Basin, offshore Brazil. Geosphere, 14(1), 215-242. https://doi.org/10.1130/GES01434.1

Rohrman, M. (2007). Prospectivity of volcanic basins: Trap delineation and acreage de-risking. AAPG Bulletin, 91(6), 915-939. https://doi. org/10.1306/12150606017

Rowan, M. (2014). Passive-margin salt basins: Hyperextension, evaporite deposition, and salt tectonics. Basin Research, 26(1), 154-182. https://doi.org/10.1111/bre.12043

Rowan, M. G., Peel, F. J., \& Vendeville, B. C. (2004). Gravity-driven fold belts on passive margins (Vol. 82). AAPG Memoir: American Association of Petroleum Geologists.

Schmiedel, T., Galland, O., \& Breitkreuz, C. (2017). Dynamics of sill and laccolith emplacement in the brittle crust: Role of host rock strength and deformation mode. Journal of Geophysical Research: Solid Earth, 122(11), 8860-8871. https://doi.org/10.1002/2017J B014468

Schmiedel, T., Galland, O., Haug, Ø., Dumazer, G., \& Breitkreuz, C. (2019). Coulomb failure of Earth's brittle crust controls growth, emplacement and shapes of igneous sills, saucer-shaped sills and laccoliths. Earth and Planetary Science Letters, 510, 161-172. https:// doi.org/10.1016/j.eps1.2019.01.011

Schofield, N., Alsop, I., Warren, J., Underhill, J. R., Lehné, R., Beer, W., \& Lukas, V. (2014). Mobilizing salt: Magma-salt interactions. Geology, 42(7), 599-602. https://doi.org/10.1130/G35406.1

Schofield, N. J., Brown, D. J., Magee, C., \& Stevenson, C. T. (2012). Sill morphology and comparison of brittle and non-brittle emplacement mechanisms. Journal of the Geological Society, 169(2), 127-141. https://doi.org/10.1144/0016-76492011-078

Schofield, N., Holford, S., Millett, J., Brown, D., Jolley, D., Passey, S. R., Muirhead, D., Grove, C., Magee, C., Murray, J., Hole, M., Jackson, C.L., \& Stevenson, C. (2017). Regional magma plumbing and emplacement mechanisms of the Faroe-Shetland Sill Complex: Implications for magma transport and petroleum systems within sedimentary basins. Basin Research, 29(1), 41-63. https://doi.org/10.1111/bre.12164

Schofield, N., Stevenson, C., \& Reston, T. (2010). Magma fingers and host rock fluidization in the emplacement of sills. Geology, 38(1), 63-66. https://doi.org/10.1130/G30142.1

Skogseid, J., Planke, S., Faleide, J. I., Pedersen, T., Eldholm, O., \& Neverdal, F. (2000). NE Atlantic continental rifting and volcanic margin formation. In A. Nottvedt (Ed.), Dynamics of the Norwegian margin (Vol. 167, pp. 295-326). Geological Society, London, Special Publications.

Spacapan, J. B., Galland, O., Leanza, H. A., \& Planke, S. (2017). Igneous sill and finger emplacement mechanism in shale-dominated 
formations: A field study at Cuesta del Chihuido, Neuquén Basin, Argentina. Journal of the Geological Society, 174(3), 422-433. https://doi.org/10.1144/jgs2016-056

Smallwood, J. R., \& Maresh, J. (2002). The properties, morphology and distribution of igneous sills: modelling, borehole data and 3D seismic from the Faroe-Shetland area. In D. W. Jolley \& B. Bell (Eds.), The North Atlantic Igneous Province: Stratigraphy, Tectonic, Volcanic and Magmatic Processes (Vol. 191, pp. 271-306). Geological Society of London Special Publication.

Stearns, D. W. (1978). Faulting and forced folding in the Rocky Mountains foreland. Geological Society of America Memoirs, 151, $1-38$.

Svensen, H., Planke, S., Jamtveit, B., \& Pedersen, T. (2003). Seep carbonate formation controlled by hydrothermal vent complexes: A case study from the Vøring Basin, the Norwegian Sea. Geo-Marine Letters, 23(3-4), 351-358.

Tari, G., Molnar, J., \& Ashton, P. (2003). Examples of salt tectonics from West Africa: A comparative approach. In T. Arthur, D. MacGregor \& N. Cameron (Eds.), Petroleum geology of Africa: New themes and developing technologies (Vol. 207, pp. 85-104). Geological Society, London, Special Publications.

Thorsen, C. E. (1963). Age of growth faulting in southeast Louisiana. Gulf Coast Association of Geological Societies Transactions, 13, 103-110.

Trude, J., Cartwright, J., Davies, R. J., \& Smallwood, J. R. (2003). New technique for dating igneous sills. Geology, 31, 4. https://doi. org/10.1130/G19559.1

Underhill, J. R. (2009). Role of intrusion-induced salt mobility in controlling the formation of the enigmatic 'Silverpit Crater', UK Southern North Sea. Petroleum Geoscience, 15(3), 197-216. https:// doi.org/10.1144/1354-079309-843
Urai, J. L., Spiers, C. J., Zwart, H. J., \& Lister, G. S. (1986). Weakening of rock salt by water during long-term creep. Nature, 324(6097), 554-557. https://doi.org/10.1038/324554a0

Van Keken, P., Spiers, C., Van den Berg, A., \& Muyzert, E. (1993). The effective viscosity of rocksalt: Implementation of steady-state creep laws in numerical models of salt diapirism. Tectonophysics, 225(4), 457-476. https://doi.org/10.1016/0040-1951(93)90310-G

Vendeville, B. C., \& Jackson, M. P. (1992). The rise of diapirs during thin-skinned extension. Marine and Petroleum Geology, 9(4), 331354. https://doi.org/10.1016/0264-8172(92)90047-I

Walker, R. J. (2016). Controls on transgressive sill growth. Geology, 44(2), 99-102. https://doi.org/10.1130/G37144.1

Warren, J. K. (2006). Evaporites: Sediments, resources and hydrocarbons. Springer Science \& Business Media.

Warren, J. K. (2010). Evaporites through time: Tectonic, climatic and eustatic controls in marine and nonmarine deposits. Earth-Science Reviews, 98(3-4), 217-268. https://doi.org/10.1016/j.earscirev.2009.11.004

\section{SUPPORTING INFORMATION}

Additional Supporting Information may be found online in the Supporting Information section.

\section{How to cite this article: Magee C, Pichel LM,} Madden-Nadeau AL, Jackson CA-L, Mohriak W. Salt-magma interactions influence intrusion distribution and salt tectonics in the Santos Basin, offshore Brazil. Basin Res. 2021;00:1-24. https://doi. org/10.1111/bre.12537 